\title{
Floristic composition of the cloud forest of the Bicentenario Reserve, Zongolica, Veracruz, México
}

\section{ccreative}

Botanical Sciences 95 (3): 1-25, 2017

DOI: $10.17129 /$ botsci.1223

Copyright: (C) 2017 Castillo-Hernández \& Flores-Olvera. This is an open access article distributed under the terms of the Creative Commons Attribution License, which permits unrestricted use, distribution, and reproduction in any medium, provided the original author and source are credited.

\section{Author Contributions}

This paper is derived from the bachelor's thesis of L. A. Castillo-Hernández guided by $\mathrm{H}$. Flores-Olvera as the main adviser. Both conducted fieldwork and contributed to the content and revisions of the paper.

Departamento de Botánica. Instituto de Biología. Universidad Nacional Autónoma de México, Ciudad de México, México

*Corresponding author: mahilda@ib.unam.mx

\section{Luis Alfonso Castillo-Hernández and Hilda Flores-Olvera*}

\section{Abstract}

Background: The Bicentenario Reserve (BR) located in Sierra de Zongolica, Veracruz, includes 63 hectares of cloud forest (cf) which lacks of systematic floristic studies, but the Sierra proposed as an area for bird conservation.

Questions: i) Is the floristic composition of the BR taxonomical rich? ii) How the growth forms are represented in this Reserve? iii) Has the BR endemic or threatened species?

Studied species: Vascular plants.

Study site and years of study: The BR was explored from March 2011 to October 2012.

Methods: Botanical samples from each species considered different were collected and processed according to conventional procedures to be identified with the use of taxonomic tools, and consults with specialist. Analysis of the richness, life forms, endemism and threatened species were made.

Results: We recorded 401 species, distributed in 272 genera and 102 families, being the most diverse Orchidaceae, Asteraceae, Fabaceae and Piperaceae; whilst Peperomia, Tillandsia, Polypodium, Quercus and Solanum are the genera with the highest number of species. Sixty-nine species are endemic to Mexico, but six are restricted to Veracruz. We found 23 new records for the municipality of Zongolica, Quercus ghiesbreghtii in the cf for the first time, and $Q$. furfuraceae for Veracruz; 86 species are threatened.

Conclusions: The BR has a high floristic richness compared to other areas with $\mathrm{cf}$ in Mexico, revealing the importance to complete the floristic studies along the Sierra de Zongolica. Due the high number of threatened species in the BR its long-term conservation acquires a greater importance.

Key words: conservation, endemism, growth forms, threatened species.

\section{Resumen}

Antecedentes: La Reserva del Bicentenario (BR) ubicada en la Sierra de Zongolica, Veracruz, contiene 63 hectáreas de bosque mesófilo (bm) que carece de estudios florísticos sistemáticos, mientras que la sierra se ha propuesto como área para la conservación de las aves.

Preguntas: i) ¿La composición florística de la BR es rica taxonómicamente? ii) ¿Cómo están representadas las formas de crecimiento en esta Reserva? iii) ¿La RB tiene especies endémicas o en peligro de extinción? Especies en estudio: Plantas Vasculares.

Sitio de estudio y fechas: La BR fue explorada de marzo de 2011 a octubre de 2012.

Métodos: Muestras botánicas de cada especie considerada diferente se colectaron y procesaron con procedimientos convencionales para ser identificadas con herramientas taxonómicas y consulta con especialistas. Se realizaron análisis de la riqueza de especies, formas de crecimiento, endemismo y especies en riesgo.

Resultados: Registramos 401 especies, distribuidas en 272 géneros y 102 familias; Orchidaceae,Asteraceae, Fabaceae y Piperaceae son las más diversas, mientras que los géneros Peperomia, Tillandsia, Polypodium, Quercus y Solanum tienen el mayor número de especies. Sesenta y nueve especies son endémicas de México y seis están restringidas a Veracruz. Encontramos 23 registros nuevos para el municipio de Zongolica, Quercus ghiesbreghtii por primera vez en bm, Q. furfuraceae en Veracruz y 86 especies amenazadas.

Conclusiones: La RB tiene una alta riqueza florística comparada con otras áreas de México con bm, revelando la importancia de completar los estudios florísticos de la Sierra de Zongolica. Debido a alto número de especies amenazadas en la RB su conservación a largo plazo adquiere gran importancia.

Palabras clave: conservación, endemismo, especies amenazadas, forma de crecimiento. 
he cloud forest (cf) (sensu Rzedowski 1978a) is a set of plant communities distributed along the mountains, having diverse structures, floristic affinities and species compositions (CONABIO 2010). They have a discontinuous distribution, but they occupy an area of 0.5 to $1 \%$ of the national territory (González-Espinosa et al. 2011, Gual-Díaz \& González-Medrano 2014). The cf concentrate a high floristic richness which goes from 2,500 to 2,822 species; the highest per unit of surface among all vegetation types in Mexico (Rzedowski 1996, Villaseñor 2010). The largest extension of cf is located in the Sierra Madre Oriental, the Sierra Norte de Oaxaca, the Sierra Madre del Sur, the Northern Chiapas mountains and the Sierra Madre de Chiapas (González-Espinosa et al.2011). This vegetation is severely threatened due to land use change, which has reduced its original cover by half (Challenger 1998) and due to only $12 \%$ of the cover in Mexico being protected (Ponce-Reyes et al. 2012).

Studies on cf have focused on both floristic and structural aspects in at least 83 localities in the country (Ruiz-Jiménez et al. 2012), but specially in Chiapas (Ramírez-Marcial 2001), State of Mexico (López-Pérez et al. 2011), Guerrero (Meave et al. 1992; Catalán-Everástio et al. 2003), Hidalgo (Luna et al. 1994, Alcántara-Ayala \& Luna-Vega 2001, Ponce-Vargas et al. 2006), Jalisco (Sánchez-Rodríguez et al. 2003), Oaxaca (Acosta-Castellanos 1997, MejíaDomínguez et al. 2004, Ruiz-Jiménez et al. 2000, Lorea \& Munn 2005), Morelos (Luna-Vega et al. 1989), Querétaro (Cartujano et al. 2002) and Tamaulipas (Cavazos-Camacho 2000).

In the state of Veracruz, the cf covers approximately 135,271 ha, with approximately 2,028 plant species (Castillo-Campos et al. 2011). The majority of the 19 studies on this vegetation type focus on the central zone of the state (Ruiz-Jiménez et al. 2012). The Sierra de Zongolica, located in the central zone of the state, is part of the physiographic province of the Sierra Madre del Sur (Medina-Chena et al. 2010). The biological exploration of the zone has been focused mainly on the knowledge of birds being proposed as an Important Area for Bird Conservation (AICA 15 Sierra de Zongolica) (Arizmendi \& Márquez-Valdemar 2000).

Regarding the botanical studies of the Sierra de Zongolica, Vázquez-Torres (1977) identified six vegetation types and contributed a list of 290 species. The floristic studies have mainly focused on the study of the epiphytes of the cloud forest in La Quinta Ecological Reserve, Zongolica (Flores-Méndez 2008, Viccon-Esquivel 2009). Etnobotanical studies of the region emphasize the cultural richness in Tlaquilpa (Pérez-Pacheco 1992, López \& Reyes 1997), Astacinga (Navarro-Pérez \& Avendaño-Reyes 2002), Soledad Atzompa (Trueba-Sánchez 2009) and Tequila (Mata-Labrada 2011, Martínez-Bolaños 2012). Montoy-Koh (2010) recorded 94 plant species in the Sierra de Zongolica useful for bees (Apis mellifera L.) 69 of them from the cf.

In the study of the cf of Mexico, CONABIO (2010) classifies the forests of the Huautla-Zongolica subregion of Sierra Norte de Oaxaca, where the area of this study is located, as forests of low quality and under a high threat, since the area is highly affected by degradation processes and by deforestation due to the demand of agricultural lands.

As a contribution to evaluate the plant richness of the Bicentenario Reserve, and to know the value for conservation we aim: i) to know the floristic composition of the BR, ii) to know the growth forms of the area, and iii) to document if there are endemic and/or threatened species to the area.

\section{Material and methods}

Area of study. The Bicentenario Reserve (Figure 1) is located northeast of the municipality of Zongolica (Figure 1B), between $18^{\circ} 39^{\prime} 01.89^{\prime \prime}$ and $18^{\circ} 39^{\prime} 27.36^{\prime \prime}$ North and $97^{\circ} 00^{\prime} 35.6$ ' and $97^{\circ} 0$ ' $55.62^{\prime \prime}$ West, along an altitudinal interval of 1,313 to $1,560 \mathrm{~m}$. It belongs to the Instituto Tecnológico Superior of Zongolica (Figure 2A) and was decreed as an Área Privada de Conservación on March 30th, 2009; it benefits about 2,000 inhabitants (Rodríguez-Luna et al. 2011). The Reserve has an extension of 63 ha and is divided in three zones: Core Area, Multiple Use Zone and Buffer Zone (Figure 1). The Reserve borders the ejido Olla Chica to the East and Northeast, whilst the rest adjoins private terrains.

Physiographically, the Bicentenario Reserve is located in the province of the Sierra Madre del Sur, within the subprovince of the Sierras Orientales, whose northern portion is known as Sierra de Zongolica, which is less abrupt than the rest of the subprovince and where Cretaceous 
Figure 1. Area of study. A) Location of the Bicentenario Reserve. B) Zonification (map modified from the one from the ITZ).

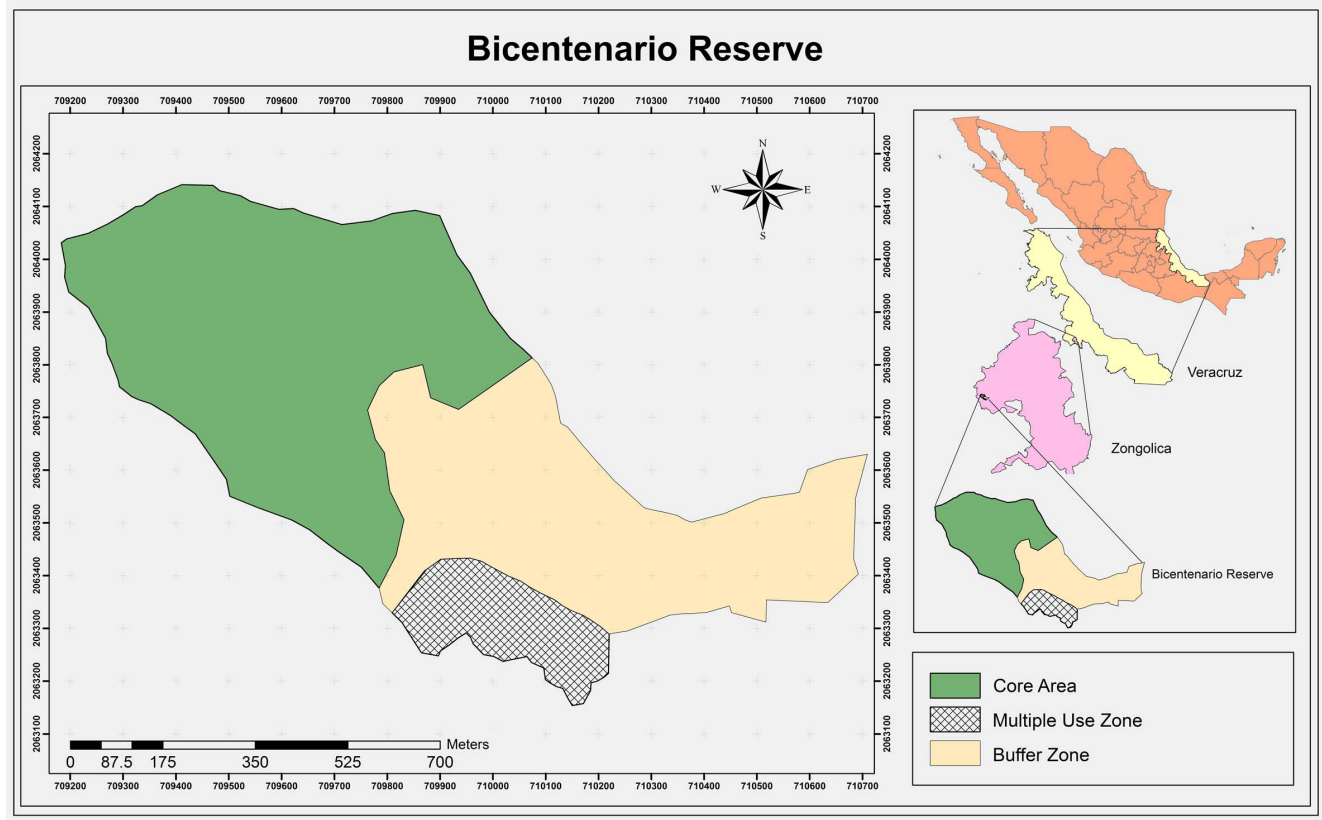

calcareous rocks predominate, giving it affinity to the Sierra Madre Oriental (Medina-Chena et al. 2010). The soil is a luvisol (INEGI 2009).

According to data from the Zongolica meteorological station $\left(18^{\circ} 40^{\prime} 00^{\prime \prime} \mathrm{N}, 97^{\circ} 00^{\prime} 00^{\prime \prime} \mathrm{W}\right.$; 1,294 meters above sea level), the climate is humid template with rains along the year. The mean annual precipitation is $2,770 \mathrm{~mm}$, and the mean annual temperature is $17.5^{\circ} \mathrm{C}$, being May the warmest month $\left(26.4^{\circ} \mathrm{C}\right)$ and February the coldest $\left(7.7^{\circ} \mathrm{C}\right)$. The mean annual number of days with mist is 48.4 (SMN, 2014) and the climate formula is C(fm)b(e) (García 1973). Regarding hydrography, the La Compañía stream is located in the southeastern limit of the area of study (Figure 2B).

Field- and deskwork. We explored the Bicentenario Reserve from March 2011 to October 2012 during nine field walks, lasting two to four days each. All the paths of the Reserve were walked in each visit. The entire plants in the case of herbs or branches of shrubs and trees, were collected from species considered distinctively different along the paths, selecting the individuals in the best state of flowering and/or fructification. The botanical samples collected were pressed in the field and dried out later at the Herbario Nacional de Mexico (MEXU). The specimens were identified in the Departamento de Botánica, in the Instituto de Biología, UNAM, with the available tools, such as electronic keys; Milliken et al. 2009 onwards, Nixon 2001-2002; regional floras, especially the Flora de Veracruz (Gómez-Pompa \& Sosa 1978-1991, Sosa 1992-2005; Castillo-Campos 2006-2013), Flora of Guatemala (McVaugh 1963, Nash \& Williams 1976,
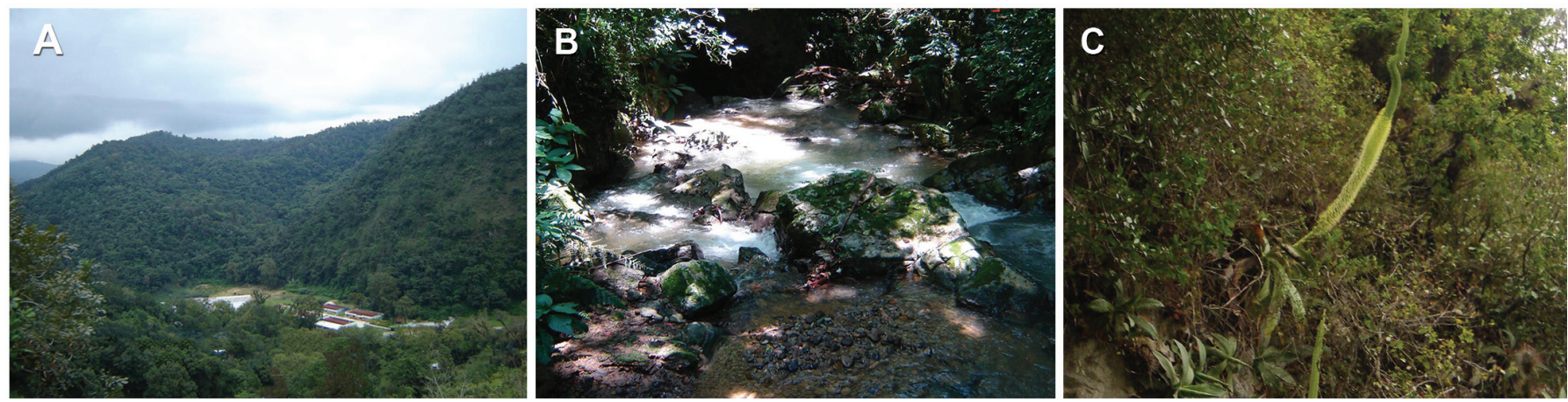

Figure 2. Area of study. A) View of the Instituto Tecnológico and the Reserve surroundings. B) La Compañía stream. C) Agave gomezpompae, endemic species to Amatlán and Zongolica, Veracruz. 
Standley \& Steyermark 1946-1958, Standley \& Williams 1961-1962, 1975. Standley et al. 1970-1974,), Flora del Bajío y de Regiones Adyacentes (Rzedowski \& Calderón de Rzedowski 1985-2013), Flora Mesoamericana (Davidse et al. 1994, 1995, 2009, 2012), Flora de Nicaragua (Stevens et al. 2009), and specialized literature such as The Pteridophytes of Mexico (Mickel \& Smith 2004), Trees and Shrubs of Mexico (Standley 1920-1926); species revisions and plant descriptions (e.g. Rzedowski 1978b, Zavala-Chávez 1989, Valencia 1995, González-Villarreal 2005, McMillan et al. 2006, Ibarra-Manríquez et al. 2012). Determinations were checked against specimens at MEXU, and images of mainly type specimens from electronic pages such as Tropicos.org and JSTOR Global Plants (2000-2013). In the cases of problematic specimens for determination experts in several groups were consulted (see acknowledgements).

In order to know the areas of distribution of the species founded in the BR, the same references used for specimen determination were consulted, as well as Luna-Vega et al. (2004), Villaseñor (2010), González-Espinosa et al. (2011), Viccon-Esquivel \& Krömer (2012), Vergara-Rodríguez (2013). In order to know the risk categories of the species in the Bicentenario Reserve, the Norma Oficial Mexicana-NOM 059 (SEMARNAT 2010) and The Red List of Mexican Cloud Forest Trees (González-Espinosa et al. 2011) were consulted.

The first duplicates of the voucher specimens were deposited in MEXU. Duplicates of these vouchers were deposited in the Instituto Tecnológico Superior de Zongolica (ITZ), the Herbario del Instituto de Ecología A.C. (XAL), and the Missouri Botanical Garden (MO).

The list of the species identified follows APG III (Stevens 2001 onwards) for the Angiosperm families, and Mickel \& Smith (2004) for pteridophytes. The species are listed alphabetically by the groups Monilophyta, Lycopodiophyta, Pinophyta and Magnoliophyta. The species names were standardized according to The International Plant Name Index.

\section{Results}

Floristic Composition. We collected 641 botanical specimens which represent 102 families, 272 genera and 401 species (Appendix 1 and Table 1). Among the groups of vascular plants, Magnoliophyta is the most numerous, followed by Monilophyta and Lycopodiophyta, whilst Pinophyta is represented by only one species (Table 1). Regarding the species number, the most diverse families are Orchidaceae with 36 (9\%), Asteraceae with 30 (7.5\%), Fabaceae with 22 (5.5\%), Rubiaceae and Polypodiaceae both with 17 each (4.2\%), Bromeliaceae with $16(4 \%)$, Piperaceae with 15 (3.7 \%), Malvaceae and Solanaceae both with 13 each (3.2\%) and Fagaceae with $11(2.7 \%)$. The rest of the families includes 211 species, corresponding to $52.6 \%$ (Table 2). The most rich families in number of genera are Asteraceae with 27 (9.9\%), Orchidaceae with $23(8.5 \%)$, Fabaceae with 18 (6.6\%), Rubiaceae with 16 (5.9\%), Malvaceae with 7 (2.6\%), Polypodiaceae and Poaceae both with 6 each $(2.2 \%)$, Lamiaceae, Melastomataceae, Pteridaceae and Urticaceae all with 5 each $(1.8 \%)$; the remaining families have 149 genera, representing $54.8 \%$ (Table 2). The genera with the largest number of species are Peperomia, Quercus, Tillandsia, Polypodium and Solanum (Table 2). The predominant growth form is herbaceous with 135 species $(33.67 \%)$, followed by trees with 82 (20.45\%), epiphytes with $79(19.70 \%)$, shrubs with $72(17.96 \%)$, climbers with $29(7.23 \%)$, arborescent with $2(0.50 \%)$, holoparasites and hemiparasites both with $1(0.25 \%)$ species each (Table 3$)$.

Forest characterization. Trees of Liquidambar styraciflua up to 20 meters height are better represented in the core area, while in the lowest part of the Reserve and along the La Compañía

Table 1. Vascular plant richness (percent in parenthesis) in the Bicentenario Reserve, Zongolica, Veracruz.

\begin{tabular}{|c|c|c|c|}
\hline Group & Number of species & Number of genera & Number of families \\
\hline Monilophyta & $42 \quad(10.47)$ & $26 \quad(9.56)$ & $12(11.77)$ \\
\hline Lycopodiophyta & $3 \quad(0.75)$ & $2 \quad(0.74)$ & $2 \quad(1.96)$ \\
\hline Pinophyta & $1 \quad(0.25)$ & $(0.37)$ & $1 \quad(0.98)$ \\
\hline Magnoliophyta & $355 \quad(88.53)$ & 243 (89.34) & 87 (85.29) \\
\hline TOTAL & 401 & 272 & 102 \\
\hline
\end{tabular}


Table 2. Families and genera with the highest number of species in the Bicentenario Reserve, Zongolica, Veracruz.

\begin{tabular}{lclc} 
Family & $\begin{array}{c}\text { Number of } \\
\text { genera/species }\end{array}$ & Genus (Family) & $\begin{array}{c}\text { Number of } \\
\text { species }\end{array}$ \\
\hline Asteraceae & $27 / 30$ & Peperomia (Piperaceae) & 11 \\
Orchidaceae & $23 / 36$ & Quercus (Fagaceae) & 11 \\
Fabaceae & $18 / 22$ & Tillandsia (Bromeliaceae) & 11 \\
Rubiaceae & $16 / 17$ & Polypodium (Polypodiaceae) & 9 \\
Malvaceae & $7 / 13$ & Solanum (Solanaceae) & 7 \\
Polypodiaceae & $6 / 17$ & Salvia (Lamiaceae) & 5 \\
Poaceae & $6 / 8$ & Miconia (Melastomataceae) & 4 \\
Lamiaceae & $5 / 10$ & Epidendrum y Prosthechea (Orchidaceae) & $4 / 4$ \\
Melastomataceae & $5 / 8$ & Smilax (Smilacaceae) & 4 \\
Pteridaceae & $5 / 6$ & Piper (Piperaceae) & 4 \\
Urticaceae & $5 / 6$ & Ipomoea (Convolvulaceae) & 4 \\
Bromeliaceae & $4 / 16$ & Maxillaria y lacquiniella (Orchidaceae) & $3 / 3$ \\
Solanaceae & $4 / 13$ & Saurauia (Actinidiaceae) & 3 \\
Piperaceae & $2 / 15$ & Cestrum (Solanaceae) & 3 \\
Fagaceae & $1 / 11$ & Desmodium (Fabaceae) & 3 \\
Total & $\mathbf{1 3 4 / 2 2 7}$ & Total & $\mathbf{9 3}$ \\
\hline
\end{tabular}

stream (Figure 2B), Platanus mexicana is the tallest tree. In the buffer zone Pinus pseudostrobus var. apulcensis is among the tallest trees with approximately $18 \mathrm{~m}$. This layer is composed by species of Carpinus, Citharexylum, Clethra (Figure. 3I), Clusia (Figure 3F), Cornus, Hedyosmum, Myriocarpa, Myrsine, Ocotea, Oreopanax, Ostrya, Phyllonoma (Figure 3E), Picramnia, Prunus, Quercus, Rhamnus, Saurauia, Symplocos, Ternstroemia, Trema, Turpinia, Viburnum, etc. Species of Bunchosia, Deppea, Erythrina, Hampea, Heliocarpus, Ilex, Juglans, Litsea, Nectandra (Figure 3A), Nyssa, and Tilia can also be found. Arborescent ferns species of Alsophila and Cyathea up to 3 or 4 meters height can be found. Towards the lowest parts of the Reserve, species of Ficus are present while in the southeastern slope close to the La Compañia stream (Figure 2B) we find Arachnothryx aff. buddleioides, Myrcianthes fragans, Perrottetia longistylis, Platanus mexicana, Siparuna thecaphora and Sommera arborescens.

In the more pronounced slopes, rupicolous species, such as Agave ellemeetiana, A. gomezpompae (Figure 2C), Echeveria rubromarginata and Tillandsia grandis are found. The epiphytes are very rich, growing in dense groups on the trunks and branches of the trees; among them there are many orchids, bromeliads, ferns and Piperaceae and Araceae species from the genera Asplenium, Brassia, Campyloneurum, Catopsis, Elaphoglossum, Epidendrum, Huperzia, Jacquiniella, Maxillaria, Monstera, Nidema, Peperomia, Phlebodium, Polypodium, Sedum, Sobralia and Tillandsia. The holoparasites and hemiparasites found in the Reserve are Conopholis alpina and Phoradendron nervosum, respectively, the latter being better represented in the zones where the Reserve borders with coffee plantations and paths.

Table 3. Life forms in the Bicentenario Reserve, Zongolica, Veracruz.

\begin{tabular}{lc} 
Growth forms & Number of species \\
\hline Herb & 135 \\
Tree & 82 \\
Epiphyte & 79 \\
Shrub & 72 \\
Climber & 29 \\
Arborescent & 2 \\
Hemiparasite & 1 \\
Holoparasite & 1 \\
Total & $\mathbf{4 0 1}$ \\
\hline
\end{tabular}



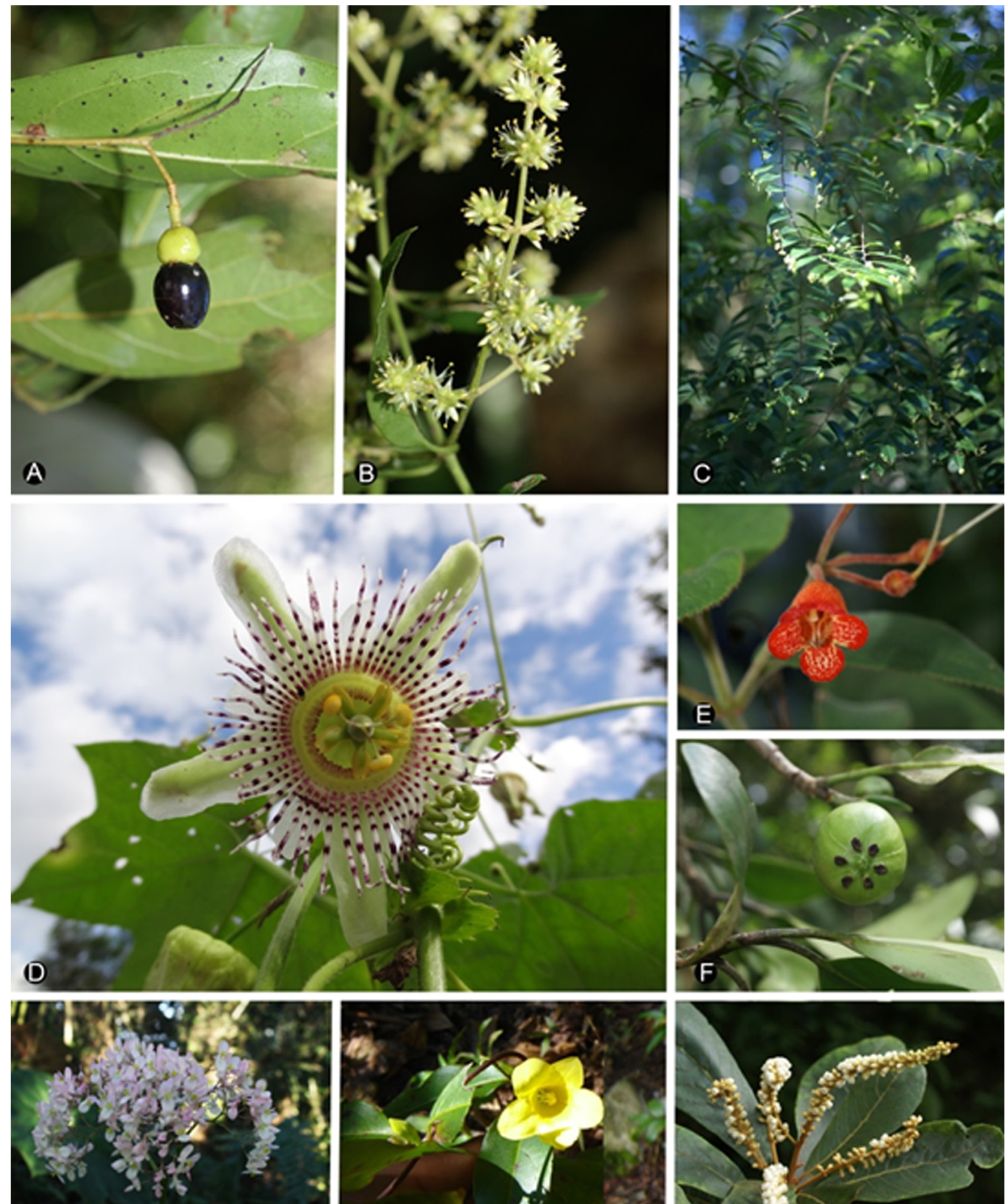

G
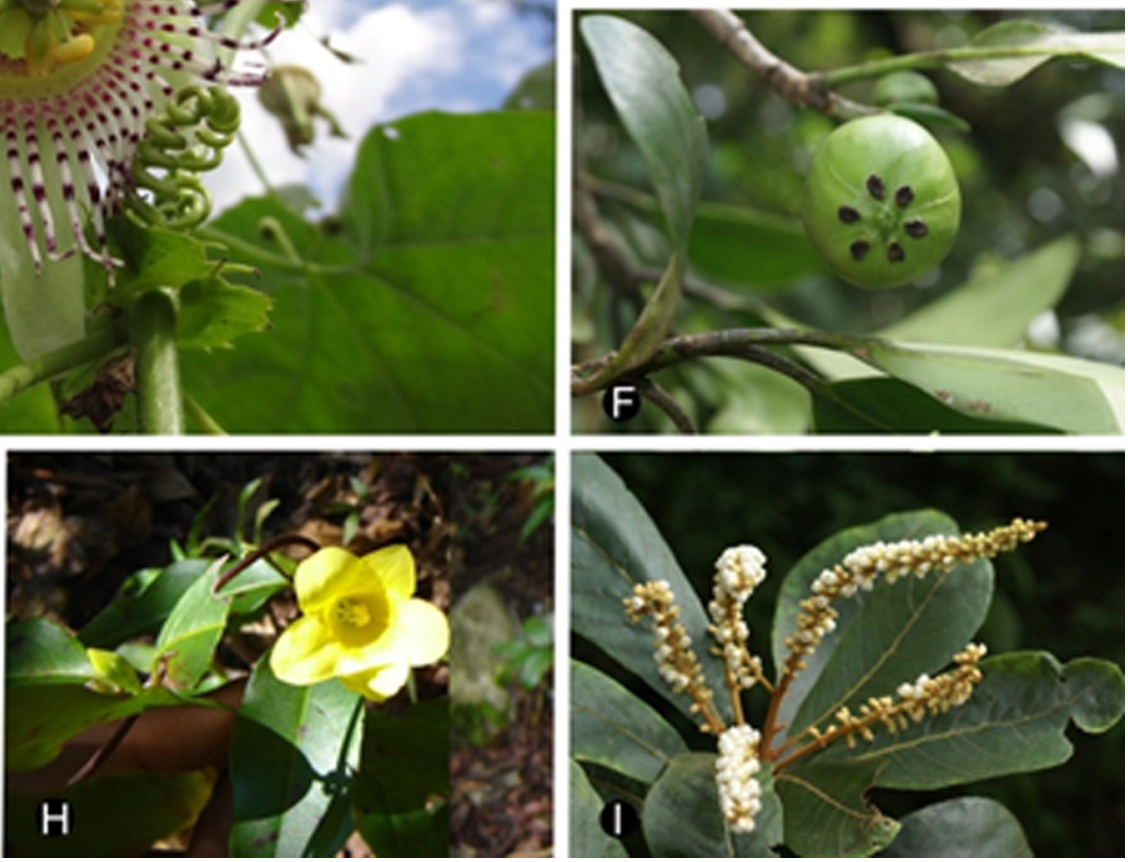

Figure 3. Some species of the flora of the Bicentenario Reserve. A) Nectandra salicifolia, near threatened. B) Iresine hebanthoides, endemic to México. C) Phyllonoma laticuspis, vulnerable. D) Passiflora adenopoda. E) Moussonia deppeana. F) Clusia flava. G) Begonia barkeri, endemic to Veracruz and Puebla. H) Gelsemium sempervirens. I) Clethra macrophylla, endemic to México. Photographies A-F by Helga Ochoterena Booth, G. by Alejandro Torres Montúfar, and H by Luis Alfonso Castillo-Hernández. 
The buffer zone and borders of the Reserve, have species of shrubs of the genera Aphelandra, Ardisia, Bartlettina, Cestrum, Chiococca, Conostegia, Gaultheria, Lepidaploa, Lyonia, Miconia, Mimosa, Moussonia (Figure 3E), Palicourea, Piper, Psychotria, Rogiera, Xylosma and Zapoteca. Among the climbers, both the herbaceous and woody ones, the best represented are Archibaccharis schiedeana, Cologania broussonetii, Clitoria mexicana, Gelsemium sempervirens (Figure 3H), Helicotropis linearis, Iresine hebanthoides (Figure 3B), Passiflora adenophora (Figure 3D), Rhynchosia longeracemosa, Selenicereus hamathus, Smilax spp, Toxicodendron radicans, Valeriana candolleana and Vitis spp. The herbaceous plants are species of Achimenes, Anthurium, Begonia (Figure 3G), Chamaedorea, Coccocypselum, Cuphea, Desmodium, Elaphoglossum, Govenia, Habenaria, Lisianthus, Oldenlandia, Peperomia, Polypodium, Salvia, Sticherus, Thelypteris, Tradescantia and Tripogandra in addition to species of Asteraceae.

Species under risk category. Out of the 401 species collected in the Reserve, 86 of them (21.44\%) are included in some of the categories in the NOM 059 (SEMARNAT 2010) or in The Red List of Mexican Cloud Forest Trees (González-Espinosa et al. 2011); four of them are cited in both lists: Litsea glaucescens, Juglans pyriformis, Carpinus caroliniana and Ostrya virginiana. Ten species are listed under some of the risk categories proposed in the NOM 059 (SEMARNAT 2010); two of them are in risk of extinction (P): Litsea glaucescens and Tilia americana var. mexicana; five are threatened (A): Psilotum complanatum, Juglans pyriformis, Chamaedorea schiedeana, Carpinus carolianiana and Tillandsia tricolor, whilst three are under special protection: (Pr) Cyathea divergens var. tuerckheimii, Alsophila firma and Ostrya virginiana. Out of the 80 species found in The Red List of Mexican Cloud Forest Trees categories (González-Espinosa et al. 2011), seven of them are Endangered (EN), 19 Vulnerable (VU), 10 Near Threatened (NT), 43 Least Concern (LC) and one Data Deficient (DD) (see Appendix 1).

Endemism. The Bicentenario Reserve contains 69 species that distributes only within the borders of Mexico and represent the $17.2 \%$ of the total found species (see Appendix 1). Six of them are known only from some parts of the state of Veracruz: Agave gomez-pompae (Figure 2C) from Amatlán and Zongolica; Clethra tuxtlensis from Los Tuxtlas and Zongolica; Erythrina berenices from Chiconquiaco, Yecuatla, Xalapa, San Andrés Tuxtla and Zongolica; Quercus ghiesbreghtii from Yecuatla, Ixhuatlán de los Reyes and Zongolica, as well as Hampea integerrima and Cuphea nitidula which are known from the central zone of the state.

New records. In the Bicentenario Reserve, were found 23 species that extend its distribution into the municipality of Zongolica. For example, Quercus furfuraceae is a new report for the state of Veracruz, since its distribution was considered previously only for Michoacán, Puebla (ValenciaA 2004), Oaxaca and San Luis Potosí (Villaseñor 2010). Quercus dysophylla was only known from the municipalities of Acultzingo, Huayacocotla and Tlalnelhuayocan, Veracruz; Quercus ghiesbreghtii, was only known from Yecuatla and Ixhuatlan de los Reyes, Veracruz, and it is the first record in a cloud forest, since it is not cited for this type of vegetation by Villaseñor (2010) or Valencia-A \& Gual-Díaz (2014). Other species that extend their distribution into the Zongolica municipality in the present contribution are Cornus excelsa known from Huayacocotla, Orizaba and Xalapa, Gelsemium semprevirens from Acajete, Atzalan, Banderilla, Calcahualco, Chiconquiaco, Coatepec, Huayacocotla, Huatusco, Jilotepec, Naolinco, Rafael Lucio, Soteapan, Tlacolulan, Tlalnelhuayocan, Xalapa and Xico, Nyssa sylvatica from Atzalan, Peperomia consoquitlana from Atoyac, Coatepec, Ixtaczoquitlan, Jilotepec, Naolinco, Orizaba, San Andrés Tuxtla and Xalapa, P. epidendron from Orizaba, Tenochtitlan, Tlacotepec de Mejia and Totula, Ponthieva rinconii from Coetzala, Racinaea ghiesbreghtii from Coatepec, Huatusco, Jilotepec, Tlalnelhuayocan, Xalapa and Xico.

\section{Discussion}

In the Bicentenario Reserve a group of families that Rzedowski (1996) considered as thriving preferentially in the cloud forest, or whose genera can thrive exclusively or almost exclusively in the cloud forest, is found. Among the former, there are Actinidiaceae, Aquifoliaceae, Begoniaceae, Clethraceae, Cornaceae, Cyatheaceae, Gesneriaceae, Gleicheniaceae, Lauraceae, Lycopodiaceae, Marattiaceae, Monimiaceae, Myrsinaceae, Orchidaceae, Piperaceae, Selaginellaceae, 
Staphyleaceae, Symplocaceae and Theaceae (Pentaphylacaceae). And among the ones whose genera thrive in the cloud forest are Chloranthaceae, Hamamelidaceae (=Altingiaceae) and Nyssaceae (=Cornaceae). Some of the tree genera with a quantitatively importance in the cloud forest (Rzedowski 1996) found in the Bicentenario Reserve are Alnus, Carpinus, Clethra, Cornus, Juglans, Liquidambar, Nyssa, Oreopanax, Prunus, Quercus, Symplocos and Ternstroemia.

The of of the Bicentenario Reserve contains a rich floristic composition with at least 401 species of vascular plants, representing the $16.4 \%$ of the floristic richness estimated for this vegetation type in Mexico by Rzedowski (1996), or $14.21 \%$ of the richness estimated by Villaseñor (2010) and the $19.77 \%$ out of the total species number recorded in the $\mathrm{cf}$ in the state of Veracruz (Castillo-Campos et al. 2011). This richness is high, taking into account the reduced sampling area $\left(63 \mathrm{ha}=0.63 \mathrm{~km}^{2}\right)$ compared to other areas studied in the state of Veracruz, such as Teocelo, where Luna et al. (1988) recorded 271 species in approximately $21 \mathrm{~km}^{2}(=2,100$ ha); Huayacocotla, where Juárez-Medina (2008) recorded 494 species from the information of three previous works and their samplings in $20 \mathrm{~km}^{2}(=2,000 \mathrm{ha})$, or La Cortadura, Coatepec, where García-Franco et al. (2008) recorded 258 species in $3,000 \mathrm{~m}^{2}\left(=0.3 \mathrm{ha},=0.003 \mathrm{Km}^{2}\right)$. In Hidalgo, 336 species were recorded in Tlanchinol (Luna et al. 1994), 359 in Lolotla (PonceVargas et al.2006), 287 in Eloxochitlan and 233 in Tahuelompa (Alcántara-Ayala \& Luna-Vega 2001). In the cf of Landa de Matamoros (Querétaro), Cartujano et al. (2002) recorded 774 species while studying an area of approximately $54 \mathrm{~km}^{2}$ and a greater sampling effort, with 14 monthly field walks, from March 1998 to April 2000, each lasting four to five days.

The high number of fern species (pteridophytes and related) found in the Bicentenario Reserve can be an indicator that the forest is conserved, since ferns require very particular environmental conditions for their growth, such as intense shade and high humidity (Williams-Linera 2012). These are the reasons for which ferns are represented by a larger number of species in the $\mathrm{cf}$ than in any other vegetation type (Challenger 1998). The presence of arborescent ferns in the Reserve shows low perturbation conditions for a long time period, in addition to them being a distinctive characteristic of the cf, due to their absence in any other type of primary vegetation (Challenger 1998, Luna et al. 2001).

Regarding growth forms, the highest numbers of species are herbs, which are better represented in the buffer zone, since logging and transit of people are common in this part of the Reserve. The borders of the Reserve favor the diversification of herbs, whereas in the core area a lower number of herbs was found. Luna et al. (2001) consider that the low amount of light penetrating the cf prevents the development and diversification of herbs, whereas its development is favored in the margins and they diversify as the disturbance increases.

The sampling of Quercus furfuracea for the first time in the state of Veracruz, of Quercus ghiesbreghtii for the first time in a cf, as well as of Peperomia consoquitlana, P. epidendron, Quercus dysophylla, Q. ghiesbreghtii, and other species which extend their known distribution into the Zongolica municipality exemplifies the need to explore the zone, which would remarkably improve the phytogeographical analyses.

It is interesting to emphasize that in the taxonomical treatments of some families of the Flora de Veracruz the presence of some species is not recorded for Zongolica, so they also extend their distribution into this municipality (e.g., Cornus excelsa, Nyssa sylvatica, Racinaea ghiesbreghtii and Gelsemium semprevirens). In this work, species of epiphytes not recorded by Flores-Méndez (2008), Viccon-Esquivel (2009), or Viccon-Esquivel \& Krömer (2012) for Zongolica were found. Among them Asplenium praemorsum, Catopsis morreniana, Dryopteris patula, Echeveria rosea, Mainthemum macrophyllum, Maxillaria cucullata, Myoxanthus congestus, Peperomia galioides, P. pililimba, P. rhexiifolia, Polypodium fraternum, P. plesiosorum, Prosthechea cochleata, $P$. chondylobulbon, Sedum botterii, Stelis emarginata, Tillandsia leiboldiana and Xylobium sulfurinum, increasing the epiphyte diversity in the municipality, even though the mentioned authors reported a greater number of species not found in the area of study.

Due to the deterioration of the vegetation in a large part of the Sierra de Zongolica and to the Reserve terrain currently being private property, it is common to find species that according to literature thrive in perturbed places, such as Bidens squarrosa, Cyclospermum leptophyllum, Elephantopus mollis, Fleischmannia pycnocephala, Gaultheria acuminata, Lantana camara, Miconia mexicana, Psidium guajava, Sida rhombifolia, Triumfetta bogotensis, Verbena carolina, 
Witheringia solanacea and Viguiera cordata. The presence of other species such as Conostegia xalapensis indicate that a secondary succession is under process, whereas other such as Epidendrum radicans and Erigeron karvinskianus are ruderals. Nonetheless, these are mainly found in the paths of the buffer zone, in the multiple-use zone and in the borders of the Reserve, where there is a larger transit of people and so the amount of light penetrating the forest is higher. In the Bicentenario Reserve there are seven introduced species Hypoestes phyllostachya, Ocimum campechianum, Ricinus communis and Trifolium repens, from the Old World (Villaseñor \& Espinosa-García 2004), Impatiens walleriana from South America, Eriobotrya japonica native from China (Pankhurst 2009) and Kalanchoe pinnata introduced from Africa and Madagascar (Brunner 2009). These species are still scarce and are found in the borders of the Reserve or in the buffer zone.

The presence in the Bicentenario Reserve of 86 species included in the NOM-059 (SEMARNAT 2010) and in the The Red List of Mexican Cloud Forest Trees (González-Espinosa et al. 2011) stress the importance of the reservation as a biodiversity refuge, protecting species of great importance in the Mexican flora. As Martínez-Camilo et al. (2012) mention, the role performed by a protected area, the Bicentenario Reserve in this case, in the conservation of biodiversity acquires a greater importance when the species under threat, in danger of extinction or in another risk category, are known. Based on this information it is possible to promote more appropriate conservation policies, focused on the species that need them, that is why these species need special attention and why actions for their conservation and preservation in the ecosystem should be taken.

\section{Conclusions}

This first contribution to the knowledge of the flora of the $\mathrm{cf}$ in the Bicentenario Reserve in particular and in the Zongolica municipality in general, emphasizes its high floristic richness, with 401 species, 272 genera and 102 families of vascular plants, representing the $19.77 \%$ of the total species number recorded in the cf of the state of Veracruz and between 14.21 and $16.04 \%$ of the floristic richness estimated for this vegetation type in Mexico.

Despite the cf of the region having been cataloged as of low quality, the remnant flora, according to the results of this work, contains a high species richness, with 69 species endemic to Mexico, out of which eight are endemic to the state of Veracruz, as well as species in some risk category and species never before recorded for the zone. The conservation of the Reserve should be a priority, nonetheless because it has ten species considered in the NOM 059 (SEMARNAT, 2010) and 80 in The Red List of Mexican Cloud Forest Trees (González-Espinosa et al. 2011).

\section{Acknowledgements}

To Miguel Ángel de la Torre Loranca, General Director of the Instituto Tecnológico Superior de Zongolica, for facilitating the making of this study. Particularly, we thank Fortino Corona Jiménez and Yavé Carrera Quirino of the ITSZ, as well as Helga Ochoterena Booth, Alejandro Torres Montufar and Nidia Mendoza Díaz, for their support and company in the field work. To the experts Oscar Hinojosa Espinoza and José Luis Villaseñor (Asteraceae), Carlos Gómez Hinostrosa (Cactaceae), Helga Ochoterena and Alejandro Torres Montufar (Rubiaceae), Alfonso Delgado (Fabaceae), Angélica Ramírez Roa (Gesneriaceae), Gerardo Salazar Chávez (Orchidaceae), Susana Valencia Ávalos (Quercus), Daniela Vergara (Peperomia), Alberto Reyes and Emily Lott, for the determination of some species or the corroboration of the identifications. We thank David Gernandt and Angélica Ramírez Roa for the support of the MEXU in mounting duplicates donated to the ITSZ. We also thank José Luis Caballero for his help in the making of Figure 1.

\section{Literature cited}

Acosta-Castellanos S. 1997. Afinidades fitogeográficas del bosque mesófilo de montaña de la zona de Pluma Hidalgo, Oaxaca, México. Polibotánica 6: 25-39. 
Alcántara-Ayala O, Luna-Vega I. 2001. Análisis florístico de dos áreas con bosque mesófilo de montaña en el estado de Hidalgo, México: Eloxochitlan y Tlahuelompa. Acta Botánica Mexicana 54: 51-87.

Arizmendi MC, Márquez-Valdemar L. 2000, eds. Áreas de importancia para la conservación de las aves en México. México: Cipamex/Conabio.

Brunner D. 2009. Crassulaceae. In: Flora de Nicaragua. <http://www.tropicos.org/Project/FN> (accessed May, 2014)

Cartujano S, Zamudio S, Alcántara O, Luna I. 2002. El bosque mesófilo de montaña en el municipio de Landa de Matamoros, Querétaro, México. Boletín de la Sociedad Botánica de México 70: 13-43.

Castillo-Campos G. 2006-2013. Flora de Veracruz. Xalapa, Veracruz: Instituto de Ecología, A.C.

Castillo-Campos G, Avendaño-Reyes S, Medina-Abreo M. 2011. Flora y vegetación. In: CONABIO. La Biodiversidad en Veracruz: Estudio de Estado. Comisión Nacional para el Conocimiento y Uso de la Biodiversidad. México: Gobierno del Estado de Veracruz Universidad Veracruzana-Instituto de Ecología A.C. 161-179.

Catalán-Everástico C, López-Mata L, Terrazas T. 2003. Estructura, composición florística y diversidad de especies leñosas de un bosque mesófilo de montaña de Guerrero, México. Anales del Instituto de Biología, Universidad Nacional Autónoma de México, Serie Botánica 74: 209-230.

Cavazos-Camacho C. 2000. Evaluación del bosque mesófilo de montaña de San Carlos, Tamaulipas. MSc. Thesis. Universidad Autónoma de Nuevo León.

Challenger A. 1998. La zona ecológica templada húmeda (el bosque mesófilo de montaña). In: Challenger A. Utilización y Conservación de los Ecosistemas Terrestres de México: Pasado, Presente y Futuro. Ciudad de México: Comisión Nacional para el Conocimiento y Uso de la Biodiversidad, Universidad Nacional Autónoma de México, Agrupación Sierra Madre, 443-486.

CONABIO 2010. El Bosque Mesófilo de Montaña en México: Amenazas y Oportunidades para su Conservación y Manejo Sostenible. Ciudad de México: Comisión Nacional para el Conocimiento y Uso de la Biodiversidad.

Davidse G, Sousa S M, Chater AO, eds. 1994. Flora Mesoamericana. Vol. 6. Alismataceae a Cyperaceae. Ciudad de México: Universidad Nacional Autónoma de México, Missouri Botanical Garden, The Natural History Museum (London).

Davidse G, Sousa S M, Knapp S, eds. 1995. Flora Mesoamericana Vol. 1.Psilotaceae a Salviniaceae. Universidad Nacional Autónoma de México. Ciudad de México: Missouri Botanical Garden, The Natural History Museum (London).

Davidse G, Sousa S M, Knapp S, Chiang-Cabrera F, eds. 2009. Flora Mesoamericana Vol. 4(1). Cucurbitaceae a Polemoniaceae. Ciudad de México: Universidad Nacional Autónoma de México, Missouri Botanical Garden, The Natural History Museum (London).

Davidse G, Sousa S M, Knapp S, Chiang-Cabrera F, eds. 2012. Flora Mesoamericana Vol.4(2). Rubiaceae a Verbenaceae. St. Louis: Missouri Botanical Garden Press.

Flores-Méndez H. 2008. Epífitas vasculares del bosque mesófilo de montaña de la comunidad La Quinta Zongolica, Ver. Trabajo practico científico. Universidad Veracruzana.

García E. 1973. Modificaciones al sistema de clasificación climática de Koppen (para adaptarlo a las condiciones de la República Mexicana). Instituto de Geografía, Universidad Nacional Autónoma de México.

García-Franco J, Castillo-Campos G, Mehltreter K, Martínez M, Vázquez G. 2008. Composición florística de un bosque mesófilo del centro de Veracruz, México. Boletín de la Sociedad Botánica de México $\mathbf{8 3}$ $37-52$.

Gómez-Pompa A, Sosa V. eds. 1978-1991. Flora de Veracruz. Instituto Nacional de Investigaciones sobre Recursos Bióticos. Xalapa, Veracruz.

González-Espinosa M, Meave JA, Lorea-Hernández FG, Ibarra-Manríquez G, Newton AC, eds. 2011. The Red List of Mexican Cloud Forest Trees. Fauna \& Flora International. Cambridge.

González-Villarreal L. 2005. Novelties Clethra (Clethraceae) from México. Ibugana 13: 11-25.

Gual-Díaz M, González-Medrano F. 2014. Los bosques mesófilos de montaña en México. In: Gual-Díaz M, Rendón-Correa A. comps. Bosques Mesófilos de Montaña de México: Diversidad, Ecología y Manejo. Ciudad de México: Comisión Nacional para el Conocimiento y Uso de la Biodiversidad, 27-67.

Ibarra-Manríquez G, Cornejo-Tenorio G, González-Castañeda N, Piedra-Malagón E, Luna A. 2012. El Género Ficus L. (Moraceae) en México. Botanical Sciences 90: 389- 452.

INEGI 2009. Prontuario de información geográfica municipal de los Estados Unidos Mexicanos. Zongolica Clave geoestadística 20201. <http://www3.inegi.org.mx/contenidos/app/mexicocifras/datos_geograficos/30/30201.pdf> (Accessed, 01/08/2017)

JSTOR Global Plants. 2000-2013. ITHAKA. < http://plants.jstor.org > (Accessed 2011-2013., )

Juárez-Medina AK. 2008. Biodiversidad de la flora del bosque mesófilo de montaña del municipio de Huayacocotla, Veracruz, México. BSc. Thesis, Universidad Nacional Autónoma de México. 
López PE, Reyes A. 1997. Exploración etnobotánica de plantas útiles en parcelas forestales del municipio de Tlaquilpa, Veracruz. BSc. Thesis. Universidad Autónoma Chapingo.

López-Pérez Y, Tejero-Diez JD, Torres-Díaz AN. Luna-Vega I. 2011. Flora del bosque mesófilo de montaña y vegetación adyacente en Avándaro, Valle de Bravo, Estado de México, México. Boletín de la Sociedad Botánica de México 88: 35-53.

Lorea F, Munn X. 2005. Estudio florístico de los bosques mesófilos de la Sierra Mazateca de Oaxaca, México. Ciudad de México: Instituto de Ecología A.C. División de Vegetación y Flora. Informe final SNIB-CONABIO proyecto No. U028.

Luna I, Almeida L, Villers L, Lorenzo I. 1988. Reconocimiento florístico y consideraciones fitogeográficas del bosque mesófilo de montaña de Teocelo, Veracruz. Boletín de la Sociedad Botánica de México 48: 35-63.

Luna I, Ocegueda S, Alcántara O. 1994. Florística y notas biogeográficas del bosque mesófilo de montaña del municipio de Tlanchinol, Hidalgo, México. Anales del Instituto de Biología, Universidad Nacional Autónoma de México, Serie Botánica 65: 31-62.

Luna I, Velázquez A, Velázquez E. 2001. México. In: Kappelle M, Brown AD, eds. Bosques Nublados del Neotrópico. Costa Rica: Instituto Nacional de Biodiversidad (INBio), Fundación Agroforestal del Noroeste de Argentina (ANA) \& World Conservation Union (IUCN), 183-229.

Luna-Vega I, Almeida-Leñero L, Llorente-Bousquets J. 1989. Florística y aspectos fitogeográficos del bosque mesófilo de montaña de las cañadas de Ocuilan, estados de Morelos y México. Anales del Instituto de Biología, Universidad Nacional Autónoma de México, Serie Botánica 59: 63-84.

Luna-Vega I, Alcántara Ayala O, Contreras-Medina R. 2004. Patterns of diversity, endemism and conservation: an example with Mexican species of Ternstroemiaceae Mirb. ex DC. (Tricolpates: Ericales). Biodiversity and Conservation 13: 2723-2739. DOI :10.1007/s10531-004-2145-2

Martínez-Bolaños KA. 2012. Plantas medicinales del Barrio de Santa Cruz, Municipio de Tequila. Un enfoque etnobotánico. BSc. Thesis. Universidad Veracruzana.

Martínez-Camilo R, Pérez-Farrera M, Martínez-Meléndez N. 2012. Listado de plantas endémicas y en riesgo de La Reserva de La Biosfera El Triunfo, Chiapas, México. Botanical Sciences 90: 263-285. DOI: $10.17129 /$ botsci.390

Mata-Labrada FA. 2011. La utilización de la flora y la religiosidad en Tequila, Veracruz: un estudio etnohistórico e interdisciplinario de un pueblo enclavado en el Bosque Mesófilo de Montaña. MSc. Thesis. Escuela Nacional de Antropología e Historia.

McMillan PD, Wyatt G, Morris R. 2006. The Begonia of Veracruz: additions and revisions. Acta Botánica Mexicana 75: 77-99.

McVaugh R. 1963. Flora of Guatemala. Chicago Natural History Museum. Part V11.

Meave J, Soto MA, Calvo LM, Paz H, Valencia S. 1992. Análisis sinecológico del bosque mesófilo de montaña de Omiltemi, Guerrero. Boletín de la Sociedad Botánica de México 52: 31- 77

Medina-Chena A, Salazar-Chimal TE, Álvarez Palacios JL. 2010. Fisiografía y suelos. In: Benítez Badillo G, Welsh Rodríguez C, coords. Patrimonio Natural. Comisión del Estado de Veracruz para la Conmemoración de la Independencia Nacional y la Revolución Mexicana. México, 29-42pp.

Mejía-Domínguez NR, Meave JA, Ruiz-Jiménez CA. 2004. Análisis estructural de un bosque mesófilo de montaña en el extremo oriental de la Sierra Madre del Sur (Oaxaca), México. Boletín de la Sociedad Botánica de México 74: 13-29.

Mickel JT, Smith AR. 2004. The Pteridophytes of Mexico. Memoirs of the New York Botanical Garden 88: $1-1092$.

Milliken W, Klitgård B, Baracat A. eds. 2009 onwards. Neotropikey - Interactive key and information resources for flowering plants of the Neotropics. <www.kew.org/neotropikey> (Accessed 2011-2013).

Montoy-Koh L. 2010. Estudio apibotánico para un mejor aprovechamiento de los recursos naturales en la región de las Montañas, Veracruz. BSc.Thesis. Instituto Tecnológico de China.

Nash DL, Williams LO. 1976. Flora of Guatemala. Field Museum of Natural History. Part XII.

Navarro-Pérez L, Avendaño-Reyes S. 2002. Flora útil del municipio de Astacinga, Veracruz, México. Polibotánica 14: 67-84.

Nixon K. 2001-2002. Plant Keys. Families of Dicotyledons. <http://www.plantsystematics.org/> (Accessed 2011-2013).

Pankhurst R. 2009. Rosaceae. In: Flora de Nicaragua. <http://www.tropicos.org/Project/FN> (Accessed 2011-2013)

Pérez-Pacheco A. 1992. Paisaje y Aprovechamiento del Suelo y la Vegetación en Tlaquilpa, Veracruz. MSc. Thesis. Colegio de Posgraduados de Chapingo.

Ponce-Reyes R, Reynoso-Rosales VH, Watson JEM, VanDerWal J, Fuller RA, Pressey RL, Possingham HP. 2012. Vulnetability of cloud forest reserves in Mexico to climate change. Nature Climate Change 2: 448-452. DOI: 10.1038/nclimate1453

Ponce-Vargas A, Luna-Vega I, Alcántara O, Ruiz-Jiménez C. 2006. Florística del bosque mesófilo de montaña de Monte Grande, Lolotla, Hidalgo, México. Revista Mexicana de Biodiversidad 77: 177-190. 
Ramírez-Marcial N. 2001. Diversidad florística del bosque mesófilo en el norte de Chiapas y su relación con México y Centroamérica. Boletín de la Sociedad Botánica de México 69: 63-76.

Rodríguez-Luna E, Gómez-Pompa A, López-Acosta JC, Velázquez-Rosas N, Aguilar Domínguez Y, Vázquez-Torres M. 2011. Atlas de los espacios naturales protegidos de Veracruz. Gobierno del Estado de Veracruz, Secretaría de Educación del Estado de Veracruz, Universidad Veracruzana, Centro de Investigaciones Tropicales.

Ruiz-Jiménez CA, Meave J, Contreras-Jiménez JL. 2000. El bosque mesófilo de la región de Puerto Soledad (Oaxaca), México: análisis estructural. Boletín de la Sociedad Botánica de México 65: 23-37.

Ruiz-Jiménez CA, Téllez-Valdés O, Luna-Vega I. 2012. Clasificación de los bosques mesófilos de montaña de México: afinidades de la flora. Revista Mexicana de Biodiversidad 83: 1110-1144. DOI: 10.7550/ $\mathrm{rmb} .29383$

Rzedowski J. 1978a. Vegetación de México. Ciudad de México: Limusa.

Rzedowski J. 1978b. Claves para la identificación de los Géneros de la Familia Compositae en México. Acta Científica Potosina 7: 1- 145.

Rzedowski J. 1996. Análisis preliminar de la flora vascular de los bosques mesófilos de montaña de México. Acta Botánica Mexicana 35: 25-44

Rzedowski J, Calderón de Rzedowski G. eds. 1985-2013. Flora del Bajío y de Regiones Adyacentes. Instituto de Ecología, A.C.

Sánchez-Rodríguez EV, López-Mata L, García-Moya E, Cuevas-Guzmán R. 2003. Estructura composición florística y diversidad de especies leñosas de un bosque mesófilo de montaña en la sierra de Manantlán, Jalisco. Boletín de la Sociedad Botánica de México 73: 17-34.

SEMARNAT [Secretaría del Medio Ambiente y Recursos Naturales]. 2010. Norma Oficial Mexicana NOM-059-SEMARNAT-2010, Protección ambiental - Especies nativas de México de flora y fauna silvestres - Categorías de riesgo y especificaciones para su inclusión, exclusión o cambio - Lista de especies en riesgo. Diario Oficial de la Federación. 2da Sección, 30 de diciembre de 2010.

SMN [Servicio Meteorológico Nacional]. 2014. <http://smn.cna.gob.mx/es/climatologia/informacion-climatologica> (Accessed 14th May, 2014).

Sosa V, ed. 1992-2005. Flora de Veracruz. Instituto de Ecología, A.C. and University of California.

Standley PC. 1920-1926. Trees and shrubs of Mexico. Contributions of United States National Herbarium 23: 1-1721.

Standley PC, Steyermark JA. 1946-1958. Flora of Guatemala. Chicago Natural History Museum, Parts I-VI.

Standley PC, Williams LO. 1961-1962. Flora of Guatemala. Chicago Natural History Museum. Part VII. Standley PC, Williams LO. 1975. Flora of Guatemala. Field Museum of Natural History. Part XI.

Standley PC, Williams LO, Gibson DN. 1970-1974. Flora of Guatemala. Field Museum of Natural History. Parts IX-X.

Stevens PF (2001 onwards). Angiosperm Phylogeny Website. Version 12. < http://www.mobot.org/MOBOT/research/APweb/ >. (Accessed 2011-2013).

Stevens WD, Ulloa C, Pool A, Montiel OM (eds.). 2009. Tropicos. Flora de Nicaragua. Monographs in Systematic Botany from the Missouri Botanical Garden 85. <http://www.tropicos.org/Project/FN> (Accessed 2012-2013).

Téllez-Velasco MA, ed. Conservación de las orquídeas en México. Ciudad de México: Instituto de Biología, Universidad Nacional Autónoma de México, 59- 64.

The International Plant Name Index <www.ipni.org > (Accessed 2011-2013, January, 2017)

Tropicos.org. Missouri Botanical Garden. <http://www.tropicos.org> (Accessed 2011-2013)

Trueba-Sánchez S. 2009. Plantas tintóreas utilizadas en artesanías textiles de lana de Soledad Atzompa, Veracruz. Xalapa: Consejo Veracruzano de Arte Popular.

Valencia S. 1995. Contribución al conocimiento del género Quercus (Fagaceae) en el estado de Guerrero, México. Contribuciones del Herbario de la Facultad de Ciencias No.1. Universidad Nacional Autónoma de México.

Valencia-A S. 2004. Diversidad del género Quercus (Fagaceae) en México. Boletín de la Sociedad Botánica de México 75: 33-53

Valencia-A S, Gual-Díaz M. 2014. La familia Fagaceae en el bosque mesófilo de montaña de México. Botanical Sciences 92: 193-204.

Vázquez-Torres V. 1977. Contribución al estudio de la vegetación de la región de Zongolica, Veracruz. Bcs. Thesis. Universidad Veracruzana.

Vergara-Rodríguez D. 2013. Diversidad y distribución de las especies del género Peperomia (Piperaceae) en el estado de Veracruz. MSc. Thesis. Universidad Veracruzana.

Viccon-Esquivel J. 2009. Riqueza y composición florística de las epífitas vasculares del Bosque Mesófilo de Montaña de las localidades de Atzalán y Zongolica, Veracruz. BSc. Thesis. Universidad Veracruzana. 
Received:

February 11th, 2017

Accepted:

April 17th, 2017
Viccon-Esquivel J, Krömer. T. 2012. Inventario de orquídeas como fuente de información para la conservación de los bosques mesófilos de Atzalán y Zongolica, Veracruz. In: Téllez-Velasco MA, ed. Conservación de las orquídeas en México. Ciudad de México: Instituto de Biología, Universidad Nacional Autónoma de México, 59-64.

Villaseñor JL. 2010. El bosque húmedo de montaña en México y sus plantas vasculares: catálogo florísticotaxonómico. Ciudad de México: Comisión Nacional para el Conocimiento y Uso de la Biodiversidad, Universidad Nacional Autónoma de México.

Villaseñor JL, Espinosa-García FJ. 2004. The alien flowering plants of Mexico. Diversity and Distributions 10: 113-123. DOI: 10.1111/j.1366-9516.2004.00059.x

Williams-Linera G. 2012. El bosque de niebla del centro de Veracruz: ecología, historia y destino en tiempos de fragmentación y cambio climático. Xalapa: Comisión Nacional para el Conocimiento y Uso de la Biodiversidad e Instituto de Ecología, A.C.

Zavala-Chávez F. 1989. Identificación de encinos de México. México: División de Ciencias Forestales, Universidad Autónoma Chapingo. 
Appendix 1. Floristic composition of the Bicentenario Reserve, Zongolica, Veracruz. Voucher number refers to the collections of the first author (LA Castillo-Hernández), except those of the Instituto Tecnológico de Zongolica marked as ITS. Categories in the NOM 059-SEMARNAT (2010): P (risk of extinction), A (threatened), Pr (special protection). The Red List of Mexican Cloud Forest Trees Categories (González-Espinosa et al. 2011): EN (endangered), VU (vulnerable), NT (near threatened), LC (least concern), DD (data deficient). * = endemic to Mexico.

\begin{tabular}{ccccc}
\hline Taxa & $\begin{array}{l}\text { Voucher } \\
\text { number }\end{array}$ & $\begin{array}{l}\text { Growth } \\
\text { form }\end{array}$ & $\begin{array}{c}\text { NOM } \\
\text { 059 }\end{array}$ & $\begin{array}{c}\text { The Red List } \\
\text { of Mexican } \\
\text { Cloud Forest } \\
\text { Trees Categories }\end{array}$ \\
\hline
\end{tabular}

\section{MONILOPHYTA}

Aspleniaceae

Asplenium cuspidatum Lam.

Asplenium miradorense Liebm.

322

416

Asplenium praemorsum Sw.

Cyatheaceae

Cyathea divergens var. tuerckheimii (Maxon)

R.M.Tryon

Alsophila firma (Baker) D.S. Conant

Dennstaedtiaceae

Pteridium aquilinum (L.) Kuhn

Dryopteridaceae

Dryopteris patula (Sw.) Underw.

* Eaphoglossum sartorii (Liebm.) Mickel

* Eaphoglossum vestitum (Schltdl. \& Cham.)

T. Moore

Phanerophlebia remotispora E.Fourn.

Polystichum distans E.Fourn.

Gleicheniaceae

Sticherus palmatus (W.Schaffn. ex E.

Fourn.) Copel

Marattiaceae

Marattia laxa Kunze

Polypodiaceae

Campyloneurum angustifolium Fée

Campyloneurum xalapense Fée

Niphidium crassifolium (L.) Lellinger

Pecluma alfredii (Rosenst.) M.G.Price

Pecluma plumula (Humb. \& Bonpl. ex

Willd.) M.G.Price

Phlebodium areolatum (Humb. \& Bonpl. ex Willd.) J.Sm.

Pleopeltis angusta var. stenoloma Farw.

Pleopeltis crassinervata T.Moore

Polypodium conterminans Liebm.

Polypodium fraternum Schltdl. \& Cham.

* Polypodium lepidotrichum (Fée) Maxon

Polypodium plebeium Schltdl. \& Cham.

Polypodium plesiosorum Kunze

Polypodium polypodioides (L.) Watt

Polypodium rhodopleuron Kunze

Polypodium subpetiolatum Hook.

*Polypodium villagranii Copel.
160

337

336

ITSZ

$562 \quad$ Epiphyte

581, 584, 612 Herb

$578 \quad$ Epiphyte

102, 280, 545 Herb

$526 \quad$ Herb

100, $308 \quad$ Herb

$534 \quad$ Herb

284, $605 \quad$ Epiphyte

604, $614 \quad$ Epiphyte

99

603

716

Epiphyte

Epiphyte

Herb

46, 48, $243 \quad$ Epiphyte

393 Herb

162-A, $244 \quad$ Epiphyte

307

585

525

51,606

162-B, 576

552

564,721

613

728
Herb

Epiphyte

Herb

Epiphyte

Epiphyte

Herb

Epiphyte

Epiphyte

Herb 
Appendix 1. Continuation.

\begin{tabular}{ccccc}
\hline Taxa & $\begin{array}{l}\text { Voucher } \\
\text { number }\end{array}$ & $\begin{array}{l}\text { Growth } \\
\text { form }\end{array}$ & $\begin{array}{c}\text { NOM } \\
059\end{array}$ & $\begin{array}{c}\text { The Red List } \\
\text { of Mexican } \\
\text { Cloud Forest } \\
\text { Trees Categories }\end{array}$ \\
\hline
\end{tabular}

\section{Psilotaceae}

Psilotum complanatum Sw.

Pteridaceae

Adiantum andicola Liebm.

Llavea cordifolia Lag.

Pityrogramma ebenea (L.) Proctor

Pteris cretica L.

Pteris longifolia L.

Vittaria bradeorum Rosenst.

Schizaeaceae

Anemia phyllitidis (L.) Sw.

Tectariaceae

Tectaria heracleifolia (Willd.) Underw.

Thelypteridaceae

Thelypteris oligocarpa (Humb. \& Bonpl. ex Willd.) Ching

Thelypteris hispidula (Decne.) C.F.Reed

Thelypteris ovata var. lindheimeri (C.Chr.)

A.R.Sm

\section{LYCOPODIOPHYTA}

Lycopodiaceae

Huperzia pithyoides (Schltdl. \& Cham.)

Holub

Huperzia taxifolia (Sw.) Trevis.

Selaginellaceae

Selaginella stellata Spring

PINOPHYTA

Pinus pseudostrobus var. apulcensis

(Lindl.) Shaw

\section{MAGNOLIOPHYTA}

Acanthaceae

Aphelandra schiedeana Schltdl. \& Cham.

Hypoestes phyllostachya Baker

Msticia pectoralis Jacq.

Odontonema callistachyum (Schltdl. \&

Cham.) Kuntze

\section{Actinidiaceae}

Saurauia leucocarpa Schltdl.

* Saurauia pedunculata Hook.

* Saurauia scabrida Hemsl.

Adoxaceae

Sambucus nigra subsp. canadensis(L.) Bolli

* Viburnum tiliifolium (Oerst.) Hemsl.

Alstroemeriaceae

Bomarea edulis (Tussac) Herb.

Altingiaceae

Liquidambar styraciflua L.
350

Epiphyte

A

101

129

ITSZ

563

601

481

161

717

586

524

24

Herb

Herb

Herb

Herb

Herb

Epiphyte

Herb

Herb

Herb

Herb

Herb

357-A Epiphyte

357-B

Epiphyte

16, 96

Epiphyte

Pinaceae

78, 79, 500 Tree

108,270

Shrub

175

22

487

Herb

Herb

Shrub

$\begin{array}{lll}453 & \text { Tree } & \text { VU } \\ 277,468,544 & \text { Tree } & \text { VU } \\ 588 & \text { Tree } & \text { NT } \\ & & \\ 472 & \text { Shrub } & \text { LC } \\ 83,171,230 & \text { Tree } & \text { VU } \\ 267 & \text { Herb } & \\ 455 & \text { Tree } & \text { LC }\end{array}$


Appendix 1. Continuation.

\begin{tabular}{ccccc}
\hline Taxa & $\begin{array}{l}\text { Voucher } \\
\text { number }\end{array}$ & $\begin{array}{l}\text { Growth } \\
\text { form }\end{array}$ & $\begin{array}{c}\text { NOM } \\
\mathbf{0 5 9}\end{array}$ & $\begin{array}{c}\text { The Red List } \\
\text { of Mexican } \\
\text { Cloud Forest } \\
\text { Trees Categories }\end{array}$ \\
\hline
\end{tabular}

\section{Amaranthaceae}

Iresine diffusa Humb. \& Bonpl. ex Willd.

19, 288, Herb

* Iresine hebanthoides Suess.

289,295

Anacardiaceae

Rhus terebinthifolia Schltdl. \& Cham.

296,328

Toxicodendron radicans (L.) Kuntze

278

Apiaceae

Cyclospermum leptophyllum (Pers.) Sprague

ex Britton \& P.Wilson

Sanicula liberta Cham. \& Schltdl.

Apocynaceae (Asclepiadaceae)

Asclepias curassavica L.

Shrub

Aquifoliaceae

* Ilex condensata Turcz.

Ilex sp.

Climber

Araceae

Anthurium scandens (Aubl.) Engl. subsp. scandens

Anthurium schlechtendalii Kunth

Monstera deliciosa Liebm.

Herb

*Syngonium sagittatum G.S.Bunting

Herb

Araliaceae

Hydrocotyle mexicana Schltdl. \& Cham.

\section{6}

315

557

Herb

Oreopanax capitatus (Jacq.) Decne. \& Planch.

$\begin{array}{ll}\text { 182, 406 } & \text { Herb } \\ 149 & \text { Epiphyte } \\ 346 & \text { Epiphyte } \\ & \\ 163 & \text { Herb } \\ 252,394, & \text { Tree } \\ 499,561 & \end{array}$

\section{Arecaceae}

148, 299, 356 Herb

A

Asparagaceae

*Agave ellemeetiana Jacobi

$360 \quad$ Herb

*Agave gomezpompae Cházaro \&

359

Herb

Jimeno-Sevilla

Maianthemum macrophyllum (M.Martens

\& Galeotti) LaFrankie

505

Epiphyte

Asteraceae

Acourtia veracruzana B.L.Turner

Herb

Ageratina ligustrina (DC.) R.M.King \& H.Rob.

Ageratum houstonianum Mill.

273,386

Shrub

Aldama dentata La Llave

20

Herb

Alloispermum integrifolium (DC.) H.Rob.

118,730

Herb

Archibaccharis hirtella (DC.) Heering

$6,382,489$

Herb

Archibaccharis schiedeana (Benth.) J.D.Jacks. 145, 146,

Climber

Bartlettina tuerckheimii (Klatt) R.M.King

Climber

297, 301

\& H.Rob.

398,400

Shrub

Bidens odorata Cav. var. odorata

150

168,729

Herb

Bidens squarrosa Kunth

113,542

Climber

Calyptocarpus wendlandii Sch.Bip.

Herb 
Appendix 1. Continuation.

\begin{tabular}{|c|c|c|c|c|}
\hline Taxa & $\begin{array}{l}\text { Voucher } \\
\text { number }\end{array}$ & $\begin{array}{l}\text { Growth } \\
\text { form }\end{array}$ & $\begin{array}{c}\text { NOM } \\
059\end{array}$ & $\begin{array}{l}\text { The Red List } \\
\text { of Mexican } \\
\text { Cloud Forest } \\
\text { Trees Categories }\end{array}$ \\
\hline $\begin{array}{l}\text { Critonia hospitalis (B.L.Rob.) R.M.King } \\
\text { \& H.Rob. }\end{array}$ & 383,495 & Tree & & \\
\hline Dahlia coccinea Cav. & 139 & Herb & & \\
\hline $\begin{array}{l}\text { Decachaeta incompta (DC.) R.M.King } \\
\text { \& H.Rob. }\end{array}$ & 247 & Shrub & & \\
\hline Bephantopus mollis Kunth & 14,384 & Herb & & \\
\hline Erigeron karvinskianus DC. & 13,426 & Herb & & \\
\hline $\begin{array}{l}\text { Feischmannia pycnocephala (Less.) R.M. } \\
\text { King \& H.Rob. }\end{array}$ & $\begin{array}{l}11,261,316 \\
404,497\end{array}$ & Herb & & \\
\hline $\begin{array}{l}\text { Feischmanniopsisleucocephala (Benth.) } \\
\text { R.M.King \& H.Rob. }\end{array}$ & 475 & Shrub & & \\
\hline $\begin{array}{l}\text { Hymenostephium cordatum (Hook. \& Arn.) } \\
\text { S.F.Blake }\end{array}$ & $287,549,722$ & Herb & & \\
\hline Lagascea helianthifolia Kunth & 366 & Shrub & & \\
\hline *Leiboldia serrata (D.Don) Gleason & 362,402 & Shrub & & \\
\hline Lepidaploa tortuosa (L.) H.Rob. & 268,401 & Shrub & & \\
\hline Piqueria trinervia Cav. & 200,428 & Herb & & \\
\hline *Roldana oaxacana (Hemsl.) H.Rob. \& Brettell & 409 & Herb & & \\
\hline $\begin{array}{l}\text { Roldana schaffneri (Sch.Bip. ex Klatt) } \\
\text { H.Rob. \& Brettell }\end{array}$ & 8,496 & Shrub & & \\
\hline *Schistocarpha bicolor Less. & 407 & Shrub & & \\
\hline Tagetes filifolia Lag. & 179 & Herb & & \\
\hline $\begin{array}{l}\text { Telanthophora grandifolia (Less.) H.Rob. } \\
\text { \& Brettell }\end{array}$ & 338 & Tree & & \\
\hline Tetrachyron manicatum Schltdl. & 387,501 & Shrub & & \\
\hline Verbesina turbacensis Kunth & 724 & Shrub & & \\
\hline \multicolumn{5}{|l|}{ Balsaminaceae } \\
\hline \multicolumn{3}{|l|}{ Begoniaceae } & & \\
\hline *Begonia barkeri Knowles \& Westc. & 335,392 & Herb & & \\
\hline Begonia sp. & 345 & Herb & & \\
\hline \multicolumn{5}{|l|}{ Betulaceae } \\
\hline Alnus acuminata Kunth & 537 & Tree & & $\mathrm{LC}$ \\
\hline Carpinus caroliniana Walter & 71 & Tree & A & NT \\
\hline Ostrya virginiana (Mill.) K.Koch & 73 & Tree & $\operatorname{Pr}$ & NT \\
\hline \multicolumn{5}{|l|}{ Bromeliaceae } \\
\hline Catopsis morreniana Mez & 228 & Epiphyte & & \\
\hline Catopsis sessiliflora (Ruiz \& Pav.) Mez & 53,566 & Epiphyte & & \\
\hline Pitcairnia heterophylla (Lindl.) Beer & 460 & Epiphyte & & \\
\hline $\begin{array}{l}\text { *Racinaea adscendens (L.B.Sm.) M.A. } \\
\text { Spencer \& L.B.Sm. }\end{array}$ & ITSZ & Epiphyte & & \\
\hline $\begin{array}{l}\text { *Racinaea ghiesbreghtii (Baker) M.A. } \\
\text { Spencer \& L.B.Sm. }\end{array}$ & 98 & Epiphyte & & \\
\hline Tillandsia butzii Mez & 464 & Epiphyte & & \\
\hline Tillandsia grandis Schltdl. & 583 & Herb & & \\
\hline *Tillandsia heterophylla E.Morren & 522 & Herb & & \\
\hline Tillandsia juncea (Ruiz \& Pav.) Poir. & ITSZ & Epiphyte & & \\
\hline * Tillandsia kirchhoffiana Wittm. & 97 & Epiphyte & & \\
\hline
\end{tabular}


Appendix 1. Continuation.

\begin{tabular}{|c|c|c|c|c|}
\hline Taxa & $\begin{array}{l}\text { Voucher } \\
\text { number }\end{array}$ & $\begin{array}{l}\text { Growth } \\
\text { form }\end{array}$ & $\begin{array}{c}\text { NOM } \\
059\end{array}$ & $\begin{array}{c}\text { The Red List } \\
\text { of Mexican } \\
\text { Cloud Forest } \\
\text { Trees Categories }\end{array}$ \\
\hline Tillandsia leiboldiana Schltdl. & 70 & Epiphyte & & \\
\hline Tillandsia multicaulis Steud. & $188-B$ & Epiphyte & & \\
\hline Tillandsia punctulata Schltdl. \& Cham. & 363 & Epiphyte & & \\
\hline Tillandsia schiedeana Steud. & ITSZ & Epiphyte & & \\
\hline Tillandsia tricolor Schltdl. \& Cham. & 58 & Epiphyte & A & \\
\hline Tillandsia viridiflora (Beer) Baker & 593 & Epiphyte & & \\
\hline \multicolumn{5}{|l|}{ Cactaceae } \\
\hline $\begin{array}{l}\text { * Selenicereus hamatus (Scheidw.) Britton } \\
\text { \& Rose }\end{array}$ & 521 & Herb & & \\
\hline \multicolumn{5}{|l|}{ Campanulaceae } \\
\hline Lobelia laxiflora Kunth & 5,306 & Herb & & \\
\hline Lobelia xalapensis Kunth & 17 & Herb & & \\
\hline \multicolumn{5}{|l|}{ Cannabaceae (Ulmaceae) } \\
\hline $\begin{array}{l}\text { Trema micrantha (L.) Blume var. micranta } \\
\text { Caprifoliaceae (Valerianaceae) }\end{array}$ & \multicolumn{3}{|c|}{ Caprifoliaceae (Valerianaceae) } & $\mathrm{LC}$ \\
\hline $\begin{array}{l}\text { Valeriana candolleana Gardner } \\
\text { Caryophyllaceae }\end{array}$ & $135,424,490$ & Climber & & \\
\hline $\begin{array}{l}\text { Drymaria gracilis Schltdl. \& Cham. } \\
\text { Chloranthaceae }\end{array}$ & \multicolumn{3}{|c|}{ Chloranthaceae } & \\
\hline $\begin{array}{l}\text { Hedyosmum mexicanum C.Cordem. } \\
\text { Clethraceae }\end{array}$ & \multicolumn{3}{|c|}{ Clethraceae } & $\mathrm{LC}$ \\
\hline *Clethra macrophylla M.Martens \& Galeotti & 246,385 & Tree & & $\mathrm{LC}$ \\
\hline *Clethra tuxtlensis L.M.González & $\begin{array}{l}61,310 \\
395,523\end{array}$ & Tree & & $\mathrm{LC}$ \\
\hline \multicolumn{5}{|l|}{ Clusiaceae } \\
\hline $\begin{array}{l}\text { Clusia flava Jacq. } \\
\text { Commelinaceae }\end{array}$ & \multicolumn{3}{|c|}{ Commelinaceae } & $\mathrm{LC}$ \\
\hline Callisia monandra (Sw.) Schult. \& Schult.f. & 177 & Herb & & \\
\hline Commelina diffusa Burm.f. & 442 & Herb & & \\
\hline Tradescantia zanonia (L.) Sw. & 45,323 & Herb & & \\
\hline Tripogandra serrulata (Vahl) Handlos & 44,255 & Herb & & \\
\hline \multicolumn{5}{|l|}{ Convolvulaceae } \\
\hline Ipomoea batatas (L.) Lam. & 180,317 & Climber & & \\
\hline *Ipomoea funis Schltdl. \& Cham. var. funis & 342 & Climber & & \\
\hline Ipomoea indica (Burm.) Merr. & 181 & Climber & & \\
\hline Ipomoea mairetii Choisy & 372 & Climber & & \\
\hline \multicolumn{5}{|l|}{ Cornaceae } \\
\hline Cornus excelsa Kunth & 281,515 & Tree & & $\mathrm{LC}$ \\
\hline Nyssa sylvatica Marshall & 528 & Tree & & $\mathrm{LC}$ \\
\hline \multicolumn{5}{|l|}{ Crassulaceae } \\
\hline *Echeveria rosea Lindl. & 463 & Epiphyte & & \\
\hline *Echeveria rubromarginata Rose & 103 & Herb & & \\
\hline Kalanchoe pinnata (Lam.) Pers. & 21 & Herb & & \\
\hline *Sedum botterii Hemsl. & 293,432 & Epiphyte & & \\
\hline \multicolumn{5}{|l|}{ Cyperaceae } \\
\hline Carex aff. standleyana Steyerm. & 520 & Herb & & \\
\hline Carex polystachya Sw. ex Wahlenb. & 304 & Herb & & \\
\hline Cyperus tenuis Sw. & 176,616 & Herb & & \\
\hline
\end{tabular}


Appendix 1. Continuation.

\begin{tabular}{|c|c|c|c|c|}
\hline Taxa & $\begin{array}{l}\text { Voucher } \\
\text { number }\end{array}$ & $\begin{array}{l}\text { Growth } \\
\text { form }\end{array}$ & $\begin{array}{c}\text { NOM } \\
059\end{array}$ & $\begin{array}{l}\text { The Red List } \\
\text { of Mexican } \\
\text { Cloud Forest } \\
\text { Trees Categories }\end{array}$ \\
\hline Rhynchospora aristata Boeckeler & 190,567 & Herb & & \\
\hline $\begin{array}{l}\text { Rhynchospora radicans (Schltdl. \& Cham.) } \\
\text { H.Pfeiff. subsp. radicans }\end{array}$ & 60 & Herb & & \\
\hline \multicolumn{5}{|l|}{ Dioscoreaceae } \\
\hline Dioscorea mexicana Scheidw. & 548 & Climber & & \\
\hline \multicolumn{5}{|l|}{ Dipentodontonaceae } \\
\hline Perrottetia longistylis Rose & 351,599 & Tree & & $\mathrm{LC}$ \\
\hline \multicolumn{5}{|l|}{ Ericaceae } \\
\hline Chimaphila maculata (L.) Pursh & 509 & Herb & & \\
\hline Gaultheria acuminata Schltdl. \& Cham. & 80,476 & Shrub & & $\mathrm{LC}$ \\
\hline Lyonia squamulosa M.Martens \& Galeotti & 314,456 & Shrub & & NT \\
\hline Vaccinium leucanthum Schltdl. & 530 & Tree & & EN \\
\hline \multicolumn{5}{|l|}{ Euphorbiaceae } \\
\hline Acalypha sp. & 242,291 & Herb & & \\
\hline Cnidoscolus multilobus (Pax) I.M.Johnst. & 462 & Tree & & $\mathrm{LC}$ \\
\hline Euphorbia graminea Jacq. & 312 & Herb & & \\
\hline Ricinus communis L. & 591 & Shrub & & \\
\hline \multicolumn{5}{|l|}{ Fabaceae } \\
\hline $\begin{array}{l}\text { Acacia angustissima (Mill.) Kuntze var. } \\
\text { angustissima }\end{array}$ & 551 & Tree & & \\
\hline Canavalia villosa Benth. & 380,570 & Climber & & \\
\hline Centrosema pubescens Benth. & 158 & Climber & & \\
\hline Chamaecrista rufa Britton \& Rose & 106 & Herb & & \\
\hline Clitoria mexicana Link & $167,207,379$ & Climber & & \\
\hline Cologania pulchella Kunth & 157 & Climber & & \\
\hline Crotalaria sagittalis L. & 253 & Herb & & \\
\hline Desmodium caripense (Kunth) G.Don & 164 & Herb & & \\
\hline *Desmodium helleri Peyr. & $\begin{array}{l}271,365,367, \\
368,422\end{array}$ & Herb & & \\
\hline Desmodium psilophyllum Schltdl. & 110 & Herb & & \\
\hline Diphysa floribunda Peyr. & $361-B$ & Tree & & NT \\
\hline *Erythrina berenices Krukoff \& Barneby & $361-\mathrm{A}$ & Tree & & \\
\hline Helicotropis linearis (Kunth) A.Delgado & 334 & Climber & & \\
\hline Inga vera Willd. & & Tree & & $\mathrm{LC}$ \\
\hline $\begin{array}{l}\text { Mimosa albida Humb. \& Bonpl. ex Willd. } \\
\text { var. albida }\end{array}$ & $151,199,378$ & Shrub & & \\
\hline *Phaseolus glabellus Piper & 119,405 & Climber & & \\
\hline $\begin{array}{l}\text { Rhynchosia longeracemosa M.Martens } \\
\text { \& Galeotti }\end{array}$ & $109,238,572$ & Climber & & \\
\hline Senna hirsuta (L.) H.S.Irwin \& Barneby & 569 & Herb & & \\
\hline $\begin{array}{l}\text { * Senna foetidissima var. grandiflora (Benth.) } \\
\text { H.S.Irwin \& Barneby }\end{array}$ & 156,374 & Shrub & & \\
\hline $\begin{array}{l}\text { Senna septemtrionalis (Viv.) H.S.Irwin } \\
\text { \& Barneby }\end{array}$ & 503 & Shrub & & \\
\hline Trifolium repens $\mathrm{L}$. & 465 & Herb & & \\
\hline $\begin{array}{l}\text { Zapoteca portoricensis (Jacq.) H.M.Hern. } \\
\text { subsp. portoricensis }\end{array}$ & $\begin{array}{l}41,282 \\
446,715\end{array}$ & Shrub & & $\mathrm{LC}$ \\
\hline
\end{tabular}


Appendix 1. Continuation.

\begin{tabular}{ccccc}
\hline Taxa & $\begin{array}{l}\text { Voucher } \\
\text { number }\end{array}$ & $\begin{array}{l}\text { Growth } \\
\text { form }\end{array}$ & $\begin{array}{c}\text { NOM } \\
\mathbf{0 5 9}\end{array}$ & $\begin{array}{c}\text { The Red List } \\
\text { of Mexican } \\
\text { Cloud Forest } \\
\text { Trees Categories }\end{array}$ \\
\hline
\end{tabular}

\section{Fagaceae}

*Quercus aff. glabrescens Benth.

$\begin{array}{lll}104 & \text { Tree } & \text { VU } \\ 609 & \text { Tree } & \\ 130,414 & \text { Tree } & \text { VU } \\ 169,220, & \text { Tree } & \\ 272,507 & & \\ 269 & \text { Tree } & \text { VU } \\ 92,49 & \text { Tree } & \\ 187 & \text { Tree } & \\ 568 & \text { Tree } & \text { LC } \\ 77 & \text { Tree } & \text { EN } \\ 239,610,611 & \text { Tree } & \text { EN } \\ 607 & \text { Tree } & \end{array}$

*Quercus aff. sartorii Liebm.

Quercus candicans Née

Quercus castanea Née

*Quercus dysophylla Benth.

Quercus elliptica Née

*Quercus furfuracea Liebm.

*Quercus ghiesbreghtii M.Martens \& Galeotti

*Quercus obtusata Bonpl.

*Quercus polymorpha Schltdl. \& Cham.

*Quercus sartorii Liebm.

276,364

Climber

Gelsemiaceae (Loganiaceae)

Gelsemium sempervirens (L.) J.St.-Hil.

Gentianaceae

* Lisianthius nigrescens Schltdl. \& Cham. var. nigrescens

Gesneriaceae

Achimenes antirrhina (DC.) C.V.Morton Achimenes grandiflora (Schltdl.) DC.

Columnea schiedeana Schltdl.

Moussonia deppeana (Schltdl. \& Cham.)

Klotzsch ex Hanst.

Heliconiaceae

Heliconia adflexa (Griggs) Standl.

Hypericaceae

Hypericum hypericoides (L.) Crantz

Vismia baccifera (L.) Triana \& Planch.

Hypoxidaceae

Hypoxis decumbens L.

Iridaceae

* Sisyrinchium schaffneri S.Watson

Juglandaceae

* Uglans pyriformis Liebm.

Lamiaceae

Hyptis atrorubens Poit.

Hyptis mutabilis (Rich.) Briq.

Ocimum campechianum Mill.

Prunella vulgaris L.

* Salvia filipes Benth.

Salvia karwinskii Benth.

* Salvia longispicata M.Martens \& Galeotti

Salvia mocinoi Benth.

Salvia purpurea Cav.

Stachys lindenii Benth.

94

$183,565-B$

565-A

471

132,262

538

88, 403

554

111, 215

18

533

331

127,339

3,93 ,

122,125

539

486

435

126

$38,131,258$

222, 423, 726

594
VU

VU

VU

LC

EN 
Appendix 1. Continuation.

\begin{tabular}{|c|c|c|c|c|}
\hline Taxa & $\begin{array}{l}\text { Voucher } \\
\text { number }\end{array}$ & $\begin{array}{l}\text { Growth } \\
\text { form }\end{array}$ & $\begin{array}{l}\text { NOM } \\
059\end{array}$ & $\begin{array}{l}\text { The Red List } \\
\text { of Mexican } \\
\text { Cloud Forest } \\
\text { Trees Categories }\end{array}$ \\
\hline \multicolumn{5}{|l|}{ Lauraceae } \\
\hline Litsea glaucescens Kunth & 251,473 & Tree & $P$ & VU \\
\hline Nectandra salicifolia (Kunth) Nees & 283 & Tree & & NT \\
\hline Ocotea helicterifolia (Meisn.) Hemsl. & 461 & Tree & & VU \\
\hline *Ocotea psychotrioides Kunth & 413 & Tree & & EN \\
\hline \multicolumn{5}{|l|}{ Lythraceae } \\
\hline Cuphea hyssopifolia Kunth & 353,354 & Shrub & & \\
\hline *Cuphea nitidula Kunth & 42,196 & Herb & & \\
\hline \multicolumn{5}{|l|}{ Malpighiaceae } \\
\hline Bunchosia lindeniana A.Juss. & $\begin{array}{l}279,411 \\
553-A\end{array}$ & Tree & & $\mathrm{LC}$ \\
\hline $\begin{array}{l}\text { Bunchosia biocellata Schltdl. } \\
\text { Malvaceae }\end{array}$ & 735 & Shrub & & \\
\hline Anoda cristata (L.) Schltdl. & 10,373 & Herb & & \\
\hline *Hampea integerrima Schltdl. & 33,300 & Tree & & NT \\
\hline Heliocarpus americanus L. & 420 & Tree & & $\mathrm{LC}$ \\
\hline Heliocarpus appendiculatus Turcz. & 469 & Tree & & $\mathrm{LC}$ \\
\hline Heliocarpus mexicanus (Turcz.) Sprague & 128 & Shrub & & $\mathrm{LC}$ \\
\hline Pavonia schiedeana Steud. & 154 & Shrub & & \\
\hline *Pavonia uniflora (Sessé \& Moc.) Fryxell & 285,369 & Shrub & & \\
\hline Sida glabra Mill. & 1,136 & Herb & & \\
\hline Sida rhombifolia L. & 399,491 & Shrub & & \\
\hline $\begin{array}{l}\text { *Tilia americana var. mexicana (Schltdl.) } \\
\text { Hardin }\end{array}$ & 575 & Tree & $\mathrm{P}$ & \\
\hline Triumfetta bogotensis DC. & 112,485 & Shrub & & \\
\hline Triumfetta grandiflora Vahl & $28,311,457$ & Shrub & & \\
\hline Triumfetta semitriloba Jacq. & 30 & Shrub & & \\
\hline \multicolumn{5}{|l|}{ Melastomataceae } \\
\hline Arthrostemma ciliatum Pav. ex D.Don & 559-A & Shrub & & \\
\hline Conostegia xalapensis (Bonpl.) D.Don ex DC. & 433,466 & Shrub & & $\mathrm{LC}$ \\
\hline $\begin{array}{l}\text { Heterocentron subtriplinervium (Link \& Otto) } \\
\text { A.Braun \& C.D.Bouché }\end{array}$ & 134,508 & Shrub & & \\
\hline Miconia affinis DC. & 39,89 & Shrub & & \\
\hline Miconia desmantha Benth. & 72,492 & Shrub & & \\
\hline Miconia glaberrima (Schltdl.) Naudin & 410 & Shrub & & $\mathrm{LC}$ \\
\hline Miconia mexicana (Bonpl.) Naudin & $\begin{array}{l}32,90 \\
206,234\end{array}$ & Tree & & VU \\
\hline $\begin{array}{l}\text { * Tibouchina galeottiana (Naudin) Cogn. } \\
\text { Monimiaceae }\end{array}$ & $527,559-B$ & Herb & & \\
\hline $\begin{array}{l}\text { Mollinedia viridiflora Tul. } \\
\text { Moraceae }\end{array}$ & 529 & Tree & & VU \\
\hline Dorstenia contrajerva L. & 719,720 & Herb & & \\
\hline Ficus aurea Nutt. & 558 & Tree & & $\mathrm{LC}$ \\
\hline Ficus velutina Humb. \& Bonpl. ex Willd. & 560 & Tree & & $\mathrm{LC}$ \\
\hline $\begin{array}{l}\text { Pseudolmedia glabrata (Liebm.) C.C.Berg } \\
\text { Myrtaceae }\end{array}$ & 454 & Tree & & $\mathrm{LC}$ \\
\hline Eugenia sp. & 347 & Tree & & \\
\hline Myrcianthes fragrans (Sw.) McVaugh & 504,615 & Tree & & \\
\hline
\end{tabular}


Appendix 1. Continuation.

\begin{tabular}{|c|c|c|c|c|}
\hline Taxa & $\begin{array}{l}\text { Voucher } \\
\text { number }\end{array}$ & $\begin{array}{l}\text { Growth } \\
\text { form }\end{array}$ & $\begin{array}{c}\text { NOM } \\
059\end{array}$ & $\begin{array}{l}\text { The Red List } \\
\text { of Mexican } \\
\text { Cloud Forest } \\
\text { Trees Categories }\end{array}$ \\
\hline Psidium guajava L. & 540 & Tree & & \\
\hline \multicolumn{5}{|l|}{ Onagraceae } \\
\hline Lopezia racemosa Cav. & $2,4,115,178$ & Herb & & \\
\hline Oenothera rosea L'Hér. ex Aiton & 173,543 & Herb & & \\
\hline \multicolumn{5}{|l|}{ Orchidaceae } \\
\hline Brassia verrucosa Lindl. & 512 & Epiphyte & & \\
\hline Coelia triptera (Sm.) G.Don ex Steud. & 470 & Epiphyte & & \\
\hline Dichaea glauca (Sw.) Lindl. & 69 & Epiphyte & & \\
\hline Dichaea neglecta Schltr. & 63 & Epiphyte & & \\
\hline Eleanthus cynarocephalus (Rchb.f.) Rchb.f. & 66,227 & Epiphyte & & \\
\hline Epidendrum radicans Pav. ex Lindl. & 91,211 & Herb & & \\
\hline Epidendrum ramosum Jacq. & $249,480,571$ & Epiphyte & & \\
\hline Epidendrum repens Cogn. & 235,303 & Epiphyte & & \\
\hline Epidendrum veroscriptum Hágsater & 166 & Epiphyte & & \\
\hline *Gongora galeata (Lindl.) Rchb.f. & 598 & Epiphyte & & \\
\hline Govenia mutica Rchb.f. & 54,186 & Herb & & \\
\hline Habenaria odontopetala Rchb.f. & 320 & Herb & & \\
\hline Isochilus major Schltdl. \& Cham. & 59 & Epiphyte & & \\
\hline Jacquiniella equitantifolia (Ames) Dressler & 459 & Epiphyte & & \\
\hline * Jacquiniella leucomelana (Rchb.f.) Schltr. & 333 & Epiphyte & & \\
\hline acquiniella teretifolia (Sw.) Britton \& P.Wilson & 202 & Epiphyte & & \\
\hline Leochilus carinatus (Knowles \& Westc.) Lindl. & 52 & Epiphyte & & \\
\hline Lycaste aromatica (Graham) Lindl. & 531 & Epiphyte & & \\
\hline Lycaste deppei (Lodd.) Lindl. & 546 & Epiphyte & & \\
\hline $\begin{array}{l}\text { Malaxis histionantha (Link, Klotzsch \& Otto) } \\
\text { Garay \& Dunst. }\end{array}$ & 547 & Herb & & \\
\hline Maxillaria cucullata Lindl. & 329-A & Epiphyte & & \\
\hline Maxillaria meleagris Lindl. & 329-B & Epiphyte & & \\
\hline Maxillaria variabilis Bateman ex Lindl. & $159,189,205$ & Epiphyte & & \\
\hline $\begin{array}{l}\text { Myoxanthus congestus (A.Rich. \& Galeotti) } \\
\text { Soto Arenas }\end{array}$ & \multicolumn{3}{|c|}{ Soto Arenas } & \\
\hline Nemaconia graminifolia Knowles \& Westc. & 142,327 & Epiphyte & & \\
\hline Nidema boothii (Lindl.) Schltr. & 427,478 & Epiphyte & & \\
\hline *Ponthieva rinconii Salazar & 114,573 & Herb & & \\
\hline $\begin{array}{l}\text { Prosthechea chondylobulbon (A.Rich. \& } \\
\text { Galeotti) W.E.Higgins }\end{array}$ & 292 & Epiphyte & & \\
\hline Prosthechea cochleata (L.) W.E.Higgins & 107,219 & Epiphyte & & \\
\hline Prosthechea ochracea (Lindl.) W.E.Higgins & $57,75,274$ & Epiphyte & & \\
\hline \multicolumn{5}{|l|}{ W.E.Higgins } \\
\hline Sobralia macrantha Lindl. & 65 & Epiphyte & & \\
\hline Stelis emarginata (Lindl.) Soto Arenas \& Solano & 47 & Epiphyte & & \\
\hline Stelis platystylis (Schltr.) Solano \& Soto Arenas & $204,233,479$ & Epiphyte & & \\
\hline $\begin{array}{l}\text { *Trichocentrum pachyphyllum (Hook.) R. } \\
\text { Jiménez \& Carnevali }\end{array}$ & 412 & Herb & & \\
\hline Xylobium sulfurinum (Lem.) Schltr. & 597 & Epiphyte & & \\
\hline \multicolumn{5}{|l|}{ Orobanchaceae } \\
\hline Castilleja arvensis Schltdl. \& Cham. & 12 & Herb & & \\
\hline
\end{tabular}


Appendix 1. Continuation.

\begin{tabular}{|c|c|c|c|c|}
\hline Taxa & $\begin{array}{l}\text { Voucher } \\
\text { number }\end{array}$ & $\begin{array}{l}\text { Growth } \\
\text { form }\end{array}$ & $\begin{array}{l}\text { NOM } \\
059\end{array}$ & $\begin{array}{l}\text { The Red List } \\
\text { of Mexican } \\
\text { Cloud Forest } \\
\text { Trees Categories }\end{array}$ \\
\hline $\begin{array}{l}\text { Conopholis alpina Liebm. } \\
\text { Oxalidaceae }\end{array}$ & 452 & Holoparasite & & \\
\hline $\begin{array}{l}\text { Biophytum dendroides(Kunth) DC. } \\
\text { Passifloraceae }\end{array}$ & $361-\mathrm{C}$ & Herb & & \\
\hline $\begin{array}{l}\text { Passiflora adenopoda DC. } \\
\text { * Passiflora conzattiana Killip }\end{array}$ & $\begin{array}{l}377,725 \\
62\end{array}$ & $\begin{array}{l}\text { Climber } \\
\text { Climber }\end{array}$ & & \\
\hline Penthaphylacaceae & & & & \\
\hline $\begin{array}{l}\text { * Ternstroemia sylvatica Schltdl. \& Cham. } \\
\text { Phyllanthaceae }\end{array}$ & 82,217 & Tree & & VU \\
\hline $\begin{array}{l}\text { Phyllanthus compressus Kunth } \\
\text { Phyllonomaceae }\end{array}$ & 438 & Herb & & \\
\hline $\begin{array}{l}\text { Phyllonoma laticuspis (Turcz.) Engl. } \\
\text { Phytolaccaceae }\end{array}$ & $26-B, 302$ & Tree & & VU \\
\hline $\begin{array}{l}\text { Phytolacca purpurascens A.Braun \& } \\
\text { C.D.Bouché }\end{array}$ & 592 & Shrub & & \\
\hline $\begin{array}{l}\text { Phytolacca rivinoides Kunth \& C.D.Bouché } \\
\text { Picramniaceae (Simaroubaceae) }\end{array}$ & 397 & Shrub & & \\
\hline $\begin{array}{l}\text { Picramnia antidesma Sw. } \\
\text { Piperaceae }\end{array}$ & $165,488,608$ & Tree & & \\
\hline *Peperomia consoquitlana C.DC. & $\begin{array}{l}55,85,86,121 \\
213,550\end{array}$ & Epiphyte & & \\
\hline Peperomia dendrophila Schltdl. \& Cham. & 56,321 & Epiphyte & & \\
\hline Peperomia donaguiana C.DC. & 216,294 & Herb & & \\
\hline *Peperomia epidendron C.DC. & $\begin{array}{l}477,553-B \\
723\end{array}$ & Herb & & \\
\hline Peperomia galioides Kunth & 236 & Epiphyte & & \\
\hline *Peperomia liebmannii C.DC. & 141,318 & Herb & & \\
\hline Peperomia obtusifolia (L.) A.Dietr. & 120 & Epiphyte & & \\
\hline Peperomia quadrifolia (L.) Kunth & 140 & Epiphyte & & \\
\hline Peperomia rhexiifolia Moritz ex C.DC. & 358 & Epiphyte & & \\
\hline Peperomia sanjoseana C.DC. & 214 & Herb & & \\
\hline Peperomia tetraphylla Hook. \& Arn. & 325 & Epiphyte & & \\
\hline Piper aduncum L. & 587 & Shrub & & $\mathrm{LC}$ \\
\hline Piper amalago L. & $37,40,123$ & Shrub & & \\
\hline Piper glabrescens (Miq.) C.DC. & 144,275 & Shrub & & \\
\hline Piper umbellatum L. & 579 & Shrub & & \\
\hline Plantaginaceae & & & & \\
\hline Plantago australis subsp. hirtella (Kunth) Rahn & 15 & Herb & & \\
\hline $\begin{array}{l}\text { Russelia coccinea (L.) Wettst. } \\
\text { Platanaceae }\end{array}$ & 248,381 & Shrub & & \\
\hline $\begin{array}{l}\text { Platanus mexicana Moric. } \\
\text { Poaceae }\end{array}$ & 418 & Tree & & NT \\
\hline Arundinella deppeana Nees ex Steud. & 431 & Herb & & \\
\hline Dichanthelium Iaxiflorum (Lam.) Gould & 203 & Herb & & \\
\hline Lasiacis nigra Davidse & 241 & Herb & & \\
\hline Lasiacis scabrior Hitchc. & 518 & Herb & & \\
\hline Lasiacis sp. & 286 & Herb & & \\
\hline *Muhlenbergia gigantea (E. Fourn.) Hitchc. & 172 & Herb & & \\
\hline
\end{tabular}


Appendix 1. Continuation.

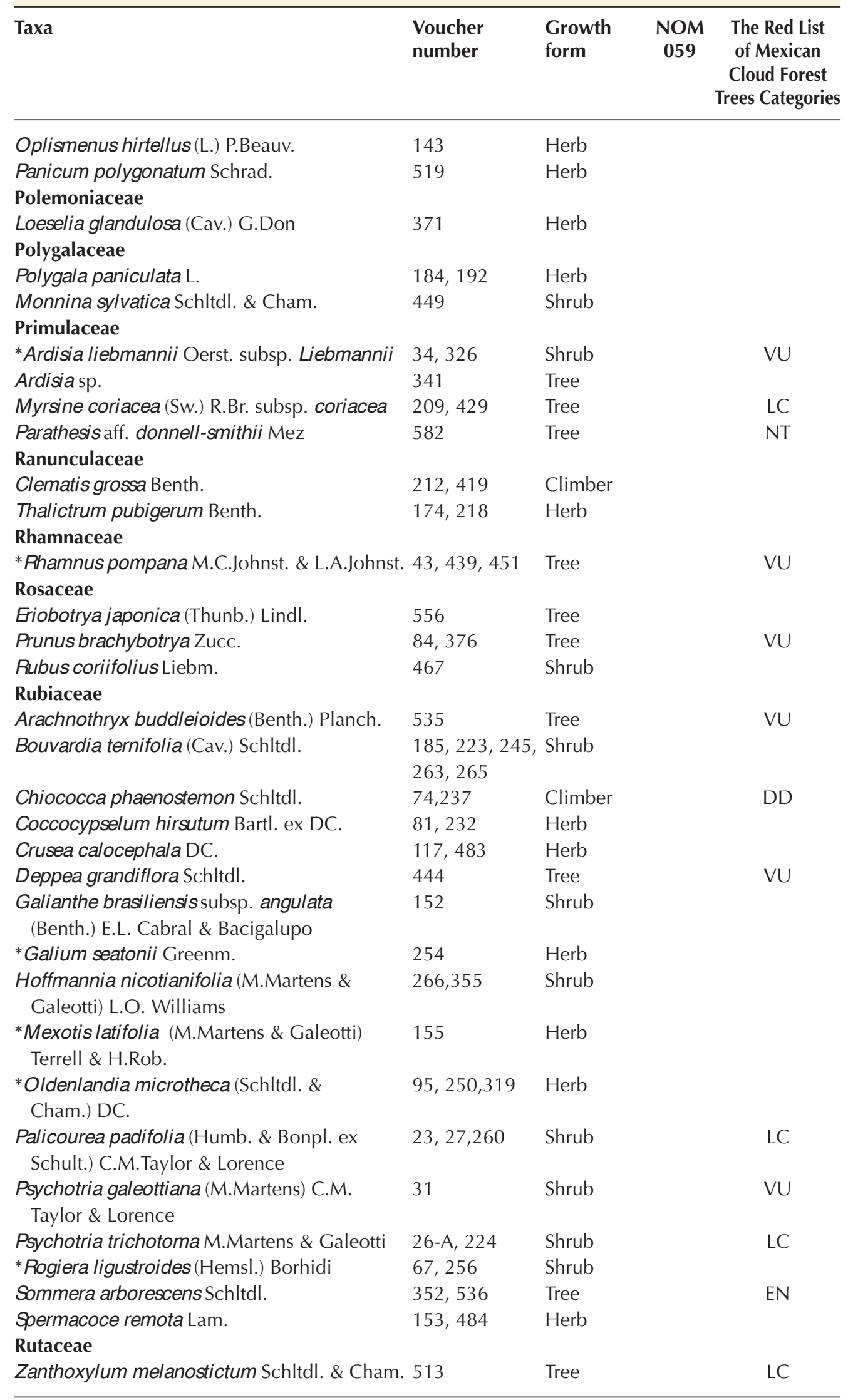


Appendix 1. Continuation.

\begin{tabular}{|c|c|c|c|c|}
\hline Taxa & $\begin{array}{l}\text { Voucher } \\
\text { number }\end{array}$ & $\begin{array}{l}\text { Growth } \\
\text { form }\end{array}$ & $\begin{array}{c}\text { NOM } \\
059\end{array}$ & $\begin{array}{l}\text { The Red List } \\
\text { of Mexican } \\
\text { Cloud Forest } \\
\text { Trees Categories }\end{array}$ \\
\hline $\begin{array}{l}\text { Zanthoxylum petenense Lundell } \\
\text { Salicaceae }\end{array}$ & 718 & Tree & & \\
\hline $\begin{array}{l}\text { Xylosma flexuosa (Kunth) Hemsl. } \\
\text { Santalaceae }\end{array}$ & $29,208,502$ & Shrub & & $\mathrm{LC}$ \\
\hline $\begin{array}{l}\text { Phoradendron nervosum Oliv. } \\
\text { Siparunaceae }\end{array}$ & 194,421 & Hemiparasite & & \\
\hline $\begin{array}{l}\text { Siparuna thecaphora (Poepp. \& Endl.) A.DC. } \\
\text { Smilacaceae (Liliaceae) }\end{array}$ & 437,595 & Tree & & $\mathrm{LC}$ \\
\hline Smilax bona-nox L. & 448,498 & Climber & & \\
\hline Smilax moranensis M.Martens \& Galeotti & $7,441,447$ & Climber & & \\
\hline Smilax mollis Humb. \& Bonpl. ex Willd. & $\begin{array}{l}64,240 \\
324,391\end{array}$ & Climber & & \\
\hline $\begin{array}{l}\text { Smilax subpubescens A.DC. } \\
\text { Solanaceae }\end{array}$ & 493 & Climber & & \\
\hline *Cestrum elegans (Brongn.) Schltdl. & $\begin{array}{l}133,195,231 \\
259,290,408\end{array}$ & Shrub & & \\
\hline Cestrum nocturnum L. & 226 & Shrub & & $\mathrm{LC}$ \\
\hline Cestrum tomentosum L.f. & 197,298 & Tree & & \\
\hline Physalis gracilis Miers & 445 & Herb & & \\
\hline *Physalis stapelioides (Regel) Bitter & 390,482 & Herb & & \\
\hline Solanum aphyodendron S.Knapp & 375,450 & Tree & & $\mathrm{LC}$ \\
\hline Solanum chrysotrichum Schltdl. & 430 & Shrub & & $\mathrm{LC}$ \\
\hline Solanum Ianceolatum Cav. & 25,494 & Shrub & & $\mathrm{LC}$ \\
\hline Solanum myriacanthum Dunal & 50 & Shrub & & \\
\hline Solanum nigrescens M.Martens \& Galeotti & 370 & Herb & & \\
\hline Solanum schlechtendalianum Walp. & 221 & Shrub & & $\mathrm{LC}$ \\
\hline Solanum sp. & 343 & Shrub & & \\
\hline $\begin{array}{l}\text { Witheringia solanacea L'Hér. } \\
\text { Staphyleaceae }\end{array}$ & 36,514 & Shrub & & \\
\hline $\begin{array}{l}\text { Turpinia insignis (Kunth) Tul. } \\
\text { Symplocaceae }\end{array}$ & 76,458 & Tree & & EN \\
\hline $\begin{array}{l}\text { Symplocos limoncillo Bonpl. } \\
\text { Urticaceae }\end{array}$ & 68,511 & Tree & & VU \\
\hline Boehmeria caudata Sw. & 440 & Tree & & $\mathrm{LC}$ \\
\hline Myriocarpa longipes Liebm. & 344,388 & Tree & & $\mathrm{LC}$ \\
\hline Phenax hirtus (Sw.) Wedd. & 589 & Shrub & & \\
\hline Pilea microphylla (L.) Liebm. & 87,188 & Herb & & \\
\hline Pilea pubescens Liebm. & 147,517 & Herb & & \\
\hline $\begin{array}{l}\text { Urera caracasana (Jacq.) Gaudich. ex Griseb. } \\
\text { Verbenaceae }\end{array}$ & 602 & Tree & & $\mathrm{LC}$ \\
\hline Citharexylum mocinnoi D.Don & $305,396,389$ & Tree & & $\mathrm{LC}$ \\
\hline Lantana camara L. & 9 & Shrub & & \\
\hline Lantana hirta Graham & 137 & Shrub & & \\
\hline $\begin{array}{l}\text { Lippia myriocephala Schltdl. \& Cham. } \\
\text { Verbena carolina L. }\end{array}$ & $\begin{array}{l}105,193 \\
541\end{array}$ & $\begin{array}{l}\text { Shrub } \\
\text { Herb }\end{array}$ & & $\mathrm{LC}$ \\
\hline Vitaceae & & & & \\
\hline Vitis popenoei J.L.Fennell & 510,596 & Climber & & \\
\hline Vitis tiliifolia Humb. \& Bonpl. ex Schult. & 474 & Climber & & \\
\hline
\end{tabular}

